UNIVERSIDADE DE SÃO PAULO

FACULDADE DE ZOOTECNIA E ENGENHARIA DE ALIMENTOS

\title{
Níveis de complexo enzimático em dietas para ruminantes
}

\author{
FERNANDO DE OLIVEIRA BRITO
}




\title{
FERNANDO DE OLIVEIRA BRITO
}

\section{Níveis de complexo enzimático em dietas para ruminantes}

\author{
Dissertação apresentada à Faculdade de \\ Zootecnia e Engenharia de Alimentos da \\ Universidade de São Paulo, como parte dos \\ requisitos para obtenção do Título de Mestre \\ em Zootecnia.
}

Área de Concentração: Qualidade e Produtividade Animal

Orientador: Prof. Dr. José Carlos Machado Nogueira Filho 
Dados Internacionais de Catalogação na Publicação

Serviço de Biblioteca e Informação da Faculdade de Zootecnia e Engenharia de Alimentos da Universidade de São Paulo

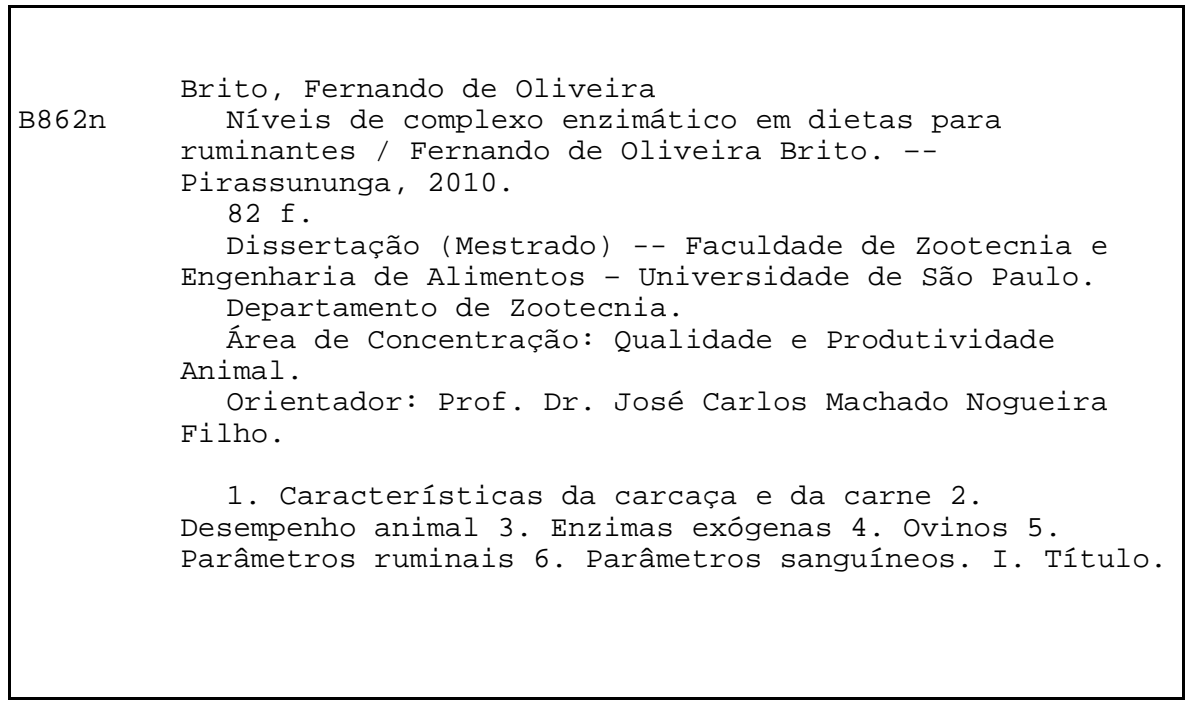




\section{DEDICATÓRIA}

มे

Meus pais, Mauro Brito e Maristela Franco de Oliveira Brito, pela compreensão, esforços sem limites e ensinamentos de vida;

Minha namorada, Jaqueline Aparecida Ignácio, pela companhia, apoio e dedicação;

Meu tio, José Jaime Pansani (in memorian), pessoa que, de certa forma, influenciou-me acertadamente na decisão pelas ciências agrárias $e$ pela qual tenho uma imensa admiração... 


\section{AGRADECIMENTOS}

Primeiramente a Deus, Mestre Supremo, que nos dá força e coragem para enfrentar os obstáculos da vida;

Aे Faculdade de Zootecnia e Engenharia de Alimentos (FZEA) da Universidade de São Paulo (USP) e todo o seu quadro de docentes e funcionários que, direta ou indiretamente, contribuíram para a conquista deste título;

Ao Prof. Dr. José Carlos Machado Nogueira Filho, orientador e amigo sem igual, pessoa de personalidade e caráter íntegros, em quem me espelho;

Aos Profs. Drs. Paulo Leme, Angélica Pereira, Saulo Silva e Júlio Balieiro, pelo apoio na condução dos trabalhos nestes dois anos de mestrado;

À minha amiga de trabalho, doutoranda Rosana Ruegger Pereira da Silva Corte, pela convivência, troca de experiências e ajuda valiosa;

À equipe que me ajudou na condução do experimento: Bruno, Daiane (Dai), Fernando Mercado, Gustavo (Dunha), Nelson (Nerso), Pedro (Tripa), Rodolfo, Viviann (Bisonha);

Aos funcionários do confinamento da FZEA, João, Manoel, Ricardo e Zanquetin, pela ajuda fundamental;

Aos funcionários do abatedouro-escola, Belone, Dito, Dorival, Elso, Mário, Maurício e Maurício (Scharlack), pelo excelente trabalho realizado;

À FAPESP, Fundação de Amparo à Pesquisa do Estado de São Paulo, pela concessão da 6olsa de mestrado (processo $n^{\circ}$ 07/57839-1) e do auxílio à pesquisa (processo no 08/54026-2); 
À Alltech do Brasil, em nome do Marcelo Manella, pelo fornecimento do produto avaliado e apoio;

Aos funcionários do Laboratório de Bromatologia do Departamento de Zootecnia da FZEA, Rafael, Rosilda e Rose, pela paciência, dedicação e ajuda na condução das análises;

Aos funcionários do Laboratório de Bromatologia do Departamento de Medicina Veterinária da $F \mathcal{F M V}$, Gilson e Simi, pelo apoio na realização da análise de amido;

Ao Prof. Dr. Marcus Zanetti e ao seu pós-doutorando Flávio Vilela, pela cessão do galpão de digestibilidade para condução de parte do experimento;

À tradicionalíssima República Pantaneira, local de confraternização frequentado por pessoas especiais em minha vida;

$\mathcal{E}$, finalmente,

Aos meus eternos amigos (as), os (as) quais conheci na faculdade e jamais me esquecerei: André (Cupim), André (Rasgada), Cesar (Baiano), Dani, Dani (Júlia), Elmeson (Mineiro), Felipe (Batatero), Felipe (Bart), Frederico (Show), Gisele (Pinga), João (Jão), Juliana (Jú Praia), Juliane (Jú Mega), Julianne (Jú Diniz), Lucas (Luquita), Luiz Henrique (Bago), Paula (Paulinha), Paulo (Simprão), Roulber, Samuel (Pastel), Victor (Preto), Viviane (Davi), e Wilson (Pijama), além de outros (as) já citados (as) anteriormente... 


\section{RESUMO}

\section{BRITO, F.O. Níveis de complexo enzimático em dietas para ruminantes. 2010. 82 f. Dissertação (Mestrado em Zootecnia) - Faculdade de Zootecnia e Engenharia de Alimentos, Universidade de São Paulo, Pirassununga, 2010.}

Foram utilizados 24 cordeiros cruzados lle de France, com peso médio inicial de 22,27 $\pm 1,85 \mathrm{~kg} \mathrm{e}$, aproximadamente, 80 dias de idade, suplementados com os níveis 0 (controle); 0,3; 0,9 e 2,7 g/kg de MS de produto enzimático comercial, contendo amilase, celulase, fitase, xilanase, betaglucanase, pectinase e protease, adicionado no momento da mistura do concentrado. O desempenho animal não foi afetado pela adição das enzimas, com médias de $37,3 \pm 4,3 \mathrm{~kg} ; 1,182 \pm 0,153$ $\mathrm{kg} / \mathrm{dia} ; 0,356 \pm 0,077 \mathrm{~kg} / \mathrm{dia}$ e 3,3 \pm 0,3 para o PVF, IMS, GPD e CA, respectivamente. Para a digestibilidade da MS, FDN, FDA, PB, EE, NDT e amido, as médias foram, respectivamente, 80,55; 60,14; 58,80; 81,55; 52,02; 83,16 e 98,20\%. A Digestibilidade da FDN apresentou uma tendência de aumento linear conforme o acréscimo do nível de enzima, com uma melhora de $11 \%$ para o último nível, em relação ao controle. As demais variáveis não foram alteradas. As concentrações de fósforo e glicose plasmáticos não foram alteradas pela enzima. O protozoário do gênero Entodinium sp. representou mais de $95 \%$ do total de ciliados para todos os tratamentos avaliados, e os dados se ajustaram ao efeito quadrático, com o nível de 2,18 $\mathrm{kg}$ de enzima/kg de MS proporcionando maior crescimento destes. Para o $\mathrm{pH}$ ruminal ao abate, não houve influência das enzimas. Os rendimentos de carcaça quente e fria apresentaram uma queda até os níveis de 1,61 e 1,55 g de enzima/kg de MS, respectivamente, sendo que, após estes valores, os rendimentos se aproximaram novamente do controle. A adição de níveis crescentes de enzimas 
diminuiu a perda de água por exsudação, mas não afetou a perda por cocção e a maciez da carne de cordeiros. Portanto, apesar da melhora em alguns parâmetros, o desempenho dos animais, bem como as características de carcaça e da carne, não foram afetados pela adição das enzimas, sendo que, para ovinos, o complexo enzimático avaliado não é eficaz sob as mesmas condições experimentais.

Palavras-chave: características da carcaça e da carne, desempenho animal, enzimas exógenas, ovinos, parâmetros ruminais, parâmetros sanguíneos. 


\begin{abstract}
Brito, F.O. Enzimatic complex levels in ruminant diets. 2010. 82 f. Dissertação (Mestrado em Zootecnia) - Faculdade de Zootecnia e Engenharia de Alimentos, Universidade de São Paulo, Pirassununga, 2010.
\end{abstract}

Twenty-four crossbred lambs lle de France, with initial average body weight of $22,7 \pm 1,85 \mathrm{~kg}$ and age of 80 days, were supplemented with 0 (control treatment); 0,$3 ; 0,9$ e $2,7 \mathrm{~g} / \mathrm{kg}$ DM levels of enzymatic commercial product, with amylase, cellulose, phytase, xylanase, glucanase, pectinase e protease, added at the moment of concentrate mixing. Performance was not affected by enzyme complex supplement,, with averages of $37,3 \pm 4,3 \mathrm{~kg} ; 1,182 \pm 0,153 \mathrm{~kg} / \mathrm{day}, 0,356 \pm 0.077$ kg/day and 3,3 \pm 0,3 for FLW, DMI, ADG and FC, respectively. For DM, NDF, ADF, CP, EE, TDN and starch, the averages were, respectively, 80,55;60,14; 58,80; 81,55; 52,$02 ; 83,16$ and $98,20 \%$. There was observed a tendency to FDN digestibility with linear increasing as the enzyme levels increased, with an improvement of $11 \%$ for the last level, compared to control diet. All the others variables were not changed. Glucose and phosphorus concentrations were not affected by the enzyme complex. The Entodinium sp. protozoa represented more than $95 \%$ of the total ciliated protozoa for all treatments studied and the data were adjusted by the quadratic effect, with the level of $2,18 \mathrm{~kg}$ of enzyme/kg of DM showing a better growing of those. Ruminal $\mathrm{pH}$ at the slaughter, was not affected by enzymes. Hot dressing percentage and cold dressing percentage decreased until levels of 1,61 and $1,55 \mathrm{~g}$ of enzyme/kg of DM, respectively, even when after these data, dressing percentage went back closely to the control treatment. The increasing levels addition of enzyme decreased drip loss, but did not affect the cocking loss and tenderness of lambs 
meat. Despite the improvement of some parameters, as well as performance, meat and carcass characteristics, were not affect by the enzymes, suggesting that enzyme complex analyzed was not efficient at the same experimental conditions for sheep.

Key words: blood parameters, carcass and meat characteristics, exogenous enzyme, performance, rumen parameters, sheep. 


\section{LISTA DE FIGURAS}

Figura 1. Galpão experimental de ovinocultura do Departamento de Zootecnia da FZEA-USP. 35

Figura 2. Cordeiros cruzados lle de France utilizados no experimento. 36

Figura 3. Baias suspensas e arreios utilizados no período de digestibilidade. .36

Figura 4. Gaiolas e arreios para coleta total de fezes. 39

Figura 5. Coleta de sangue pela veia jugular, através de tubos vacuntainers. .41

Figura 6. Aparelho Elisa conectado ao computador, com software especializado, para cálculo das concentrações de glicose plasmática.

Figura 7. Incisão ventral no rúmen para a coleta de líquido ruminal e posterior determinação do $\mathrm{pH}$.

Figura 8. Carcaça limpas, dos cordeiros utilizados no experimento, para determinação dos pesos e rendimentos e demais avaliações posteriores.

44

Figura 9. Determinação da temperatura $\left({ }^{\circ} \mathrm{C}\right)$ e $\mathrm{pH}$, no músculo Longissimus, das meias-carcaças esquerda .45

Figura 10. Amostras do músculo Longissimus, suspensas na câmara fria, dentro de redes acondicionadas em sacos inflados, evitando-se o contato das amostras com estes. .46

Figura 11. Determinação do índice de compacidade das meias-carcaças esquerda.

Figura 12. Mensuração da área de olho-de-lombo do músculo Longissimus, entre a $12^{\mathrm{a}}$ e $13^{\mathrm{a}}$ costelas. 
Figura 13. Retirada dos cilindros do músculo Longissimus (à esquerda) para mensuração da maciez através do aparelho Warner Bratzler Shear Force. 49

Figura 14. Valores médios do peso vivo inicial $(\mathrm{PVI})$ e final $(\mathrm{PVF})$ dos animais que receberam os diferentes níveis de enzima. 54

Figura 15. Valores médios da ingestão de matéria seca (IMS), ganho de peso diário (GPD) e conversão alimentar ( $C A=\mathrm{kg}$ ingerido/kg ganho) dos animais que receberam os diferentes níveis de enzima. .54

Figura 16. Regressão e equação estimadas do ganho de peso diário dos animais que receberam os diferentes níveis de enzima durante o período experimental. .56

Figura 17. Regressão e equação estimadas da ingestão de matéria seca em relação ao peso vivo (\%PV) dos animais que receberam os diferentes níveis de enzima durante o período experimental. .57

Figura 18. Variação da ingestão de matéria seca (IMS) dos animais que receberam os diferentes níveis de enzima durante o período experimental. .58

Figura 19. Regressão e equação estimadas da digestibilidade da fibra em detergente neutro (FDN) para os diferentes níveis de enzima. 60

Figura 20. Regressão e equação estimadas da digestibilidade da fibra em detergente ácido (FDA) para os diferentes níveis de enzima. 60

Figura 21. Regressão e equação estimadas das concentrações de fósforo plasmático dos animais durante o período experimental. .63

Figura 22. Regressão estimada das concentrações de glicose plasmática dos animais durante os dias de experimento, para os diferentes níveis de enzima. 64 
Figura 23. Regressões e equações estimadas do número de protozoários ruminais total e do gênero Entodinium para os diferentes níveis de enzima. 66

Figura 24. $\mathrm{pH}$ ruminal, mensurado ao abate, dos animais que receberam os diferentes níveis de enzima.

Figura 25. Regressões e equações estimadas dos rendimentos de carcaça quente (RCQ) e fria (RCF) dos animais que receberam os diferentes níveis de enzima. 70

Figura 26. Regressão e equação estimadas da temperatura da carcaça, 24 horas após abate, dos animais que receberam os diferentes níveis de enzima. 71

Figura 27. Regressão e equação estimadas da capacidade de retenção de água (CRA) da carne dos animais que receberam os diferentes níveis de enzima. .72

Figura 28. Regressão e equação estimadas da perda de água por exsudação (PAE) da carne dos animais que receberam os diferentes níveis de enzima. ..74

Figura 29. Regressão e equação estimadas das perdas por cocção (PPC) do músculo Longissimus, maturado por sete dias ou não. .74

Figura 30. Regressão e equação estimadas da força de cisalhamento (FC) aplicada ao músculo Longissimus, maturado por sete dias ou não. .75 


\section{LISTA DE TABELAS}

Tabela 1. Composição percentual e química das dietas experimentais. 37

Tabela 2. Valor médio, mínimo e máximo e coeficiente de variação (CV) das análises realizadas no presente estudo 52

Tabela 3. Valores médios dos dados de desempenho dos animais que receberam os diferentes níveis de enzimas. .53

Tabela 4. Valores médios da digestibilidade dos nutrientes e amido da dieta adicionada dos diferentes níveis de enzima. 59

Tabela 5. Valores médios das concentrações plasmáticas de fósforo $(P)$ e glicose (Gli) dos animais que receberam os diferentes níveis de enzima. 62

Tabela 6. Valores médios, erro padrão da média (EPM), probabilidades dos efeitos da regressão e coeficiente de determinação $\left(R^{2}\right)$ da população de protozoários ciliados do rúmen dos animais que receberam os diferentes níveis de enzima 65

Tabela 7. Valores médios das características da carcaça dos animais que receberam os diferentes níveis de enzima. 69

Tabela 8. Valores médios da perda de água por exsudação (PAE), perdas por cocção (PPC) e força de cisalhamento $(F C)$ da carne, maturada por 7 dias ou não, dos animais que receberam os diferentes níveis de enzima. 


\section{LISTA DE ABREVIATURAS}

$\begin{array}{ll}\text { AOL } & \text { Área de olho de lombo } \\ \text { CA } & \text { Conversão alimentar } \\ \text { CD }_{\text {ap }} & \text { Coeficiente de digestibilidade aparente } \\ \text { EE } & \text { Extrato etéreo } \\ \text { EGS } & \text { Espessura de gordura subcutânea } \\ \text { EPM } & \text { Erro padrão da média } \\ \text { FDA } & \text { Fibra em detergente ácido } \\ \text { FDN } & \text { Fibra em detergente neutro } \\ \text { GPD } & \text { Ganho de peso diário } \\ \text { IMS } & \text { Ingestão de matéria seca } \\ \text { L } & \text { Lignina } \\ \text { MS } & \text { Matéria seca } \\ \text { NDT } & \text { Nutrientes digestíveis totais } \\ \text { PB } & \text { Proteína bruta } \\ \text { PDR } & \text { Proteína degradável no rúmen } \\ \text { PVF } & \text { Peso vivo final } \\ \text { PVI } & \text { Peso vivo inicial }\end{array}$




\section{SUMÁRIO}

1.1 JUSTIFICATIVA

1.2 OBJetivo

19

2 REVISÃO DA LITERATURA

21

2.1 VARIABILIDADE DE RESPOSTA

2.1.1 NÍVEIS DE ENZIMAS

25

2.1.2 TEOR DE UMIDADE DO ALIMENTO

27

2.1.3 MÉTODOS DE APLICAÇÃO DAS ENZIMAS SOBRE O ALIMENTO

28

2.1.4 PROPORÇÃO VOLUMOSO:CONCENTRADO DA DIETA

29

2.2 UTILIZAÇÃO DE AMILASE

2.3 UTILIZAÇÃO DE FITASE

2.4 AvALIAÇÃo DE PRODUTOS ENZIMÁTICOS NA ESPÉCIE OVINA

3.1 LOCAL, ANIMAIS E ALIMENTAÇÃO

3.2 DESEMPENHO ANIMAL

3.3 DIGESTIBILIDADE APARENTE DOS NUTRIENTES E DO AMIDO 
3.4.1 FÓSFORO 41

3.4.2 GLICOSE

3.5 PARÂMETROS RUMINAIS

3.5.1 PROTOZOÁRIOS CILIADOS 42

3.5.2 $\mathrm{PH} \quad 43$

3.6 CaRActerísticas da CARCAÇA E dA CARNE 43

3.6.1 ABATE E RENDIMENTO DE CARCAÇA

3.6.2 TEMPERATURA EPH 44

3.6.3 CAPACIDADE DE RETENÇÃO DE ÁGUA 45

3.6.4 ÍNDICE DE COMPACIDADE 46

3.6.5 ÁREA DE OLHO-DE-LOMBO E ESPESSURA DE GORDURA SUBCUTÂNEA 47

3.6.6 PERDA DE ÁGUA POR EXSUDAÇÃO, PERDAS POR COCÇÃO E MACIEZ 48

$\begin{array}{ll}3.7 & \text { ANÁLISE ESTATÍSTICA }\end{array}$

4 RESULTADOS E DISCUSSÃO

4.1 Desempenho ANIMAL 53

4.2 DigeSTIBILIDADE APARENTE DOS NUTRIENTES E DO AMIDO 58

4.3 Parâmetros sanguíneos 61

$\begin{array}{ll}\text { 4.4 PARÂMETROS RUMINAIS } & 65\end{array}$

4.5 CARACTERÍSticas dA CARCAÇA E DA CARNE 68

5 CONCLUSÃO $\quad 76$

REFERÊNCIAS $\quad 77$ 


\section{INTRODUÇÃO}

O uso de enzimas exógenas como forma de melhorar a utilização dos alimentos pelos animais não é recente. Esta tecnologia é muito comum em dietas de suínos e aves; contudo, em dietas para ruminantes, sua utilização é relativamente recente (os primeiros relatos datam da década de 60). Isso porque havia uma crença generalizada de que as enzimas seriam rapidamente degradadas no rúmen antes de promoverem qualquer efeito (BEAUCHEMIN et al., 1999b), e acreditava-se que, pelo fato da atividade fibrolítica dentro do ambiente ruminal ser normalmente alta, não seria fácil aumentá-la com a simples adição de produtos enzimáticos exógenos.

Entretanto, Morgavi et al. (2000), verificando a estabilidade de enzimas no líquido ruminal, concluíram que, para a maioria delas, isso não constitui um fator limitante para sua utilização em dietas para ruminantes. Beauchemin et al. (1998, citado por BEAUCHEMIN et al., 1999) encontraram evidências de que a aplicação de enzimas, principalmente na forma líquida, sobre os alimentos, aumenta sua adsorção, com consequente aumento da resistência das enzimas à proteólise, o que prolongaria sua viabilidade no ambiente ruminal.

Sabe-se que as condições ideais para atuação da maior parte das enzimas comerciais são temperatura de, aproximadamente, $60^{\circ} \mathrm{C}$ e pH entre 4 e 5 (Coughlan, 1985). Essas condições não representam as do rúmen, que possui temperatura em torno de $39^{\circ} \mathrm{C}$ e pH entre 6,0 e 6,7 (BEAUCHEMIN et al., 2003). Entretanto, preparações enzimáticas de celulose/hemicelulose proporcionam atividade fibrolítica satisfatória em $\mathrm{pH} 4,5$, quando a atividade celulolítica microbiana, geralmente, está muito diminuta. A adição de enzimas, portanto, poderia minimizar os efeitos depressores da digestão da fibra durante períodos de baixo $\mathrm{pH}$, como no caso do fornecimento de dietas com alto concentrado (PITT, 1990, citado por LOURES et al., 
2005). Beauchemin et al. (1999) citam que este mecanismo poderia explicar as respostas de produção obtidas em dietas para vacas de leite e bovinos em terminação.

Após Beauchemin et al. (1995) constatarem melhora do desempenho animal com a utilização de soluções enzimáticas sobre alimentos secos, estes enfatizaram que os aditivos enzimáticos em dietas para ruminantes deveriam ser reavaliados.

Sabe-se que a adição de enzimas em dietas com forragem pode melhorar a digestibilidade da fibra (Beauchemin et al., 1995; Feng et al., 1996). Já, a melhora do desempenho animal dependerá do estado fisiológico deste, bem como das condições experimentais. Respostas animais serão tão maiores quanto menor a digestibilidade da fibra da dieta ou quando a energia for o nutriente limitante.

As enzimas atuam destruindo as "barreiras" da parede celular e alguns compostos químicos que impedem a adesão dos microrganismos nas células vegetais, podendo provocar um aumento da população microbiana ruminal por disponibilizar mais substratos e, conseqüentemente, nutrientes.

A celulose e a hemicelulose, os polissacarídeos estruturais mais importantes das plantas (carboidratos estruturais e fibrosos), são convertidas em açúcares solúveis por enzimas denominadas celulases e hemicelulases, respectivamente. Os tipos de celulases e hemicelulases podem diferir substancialmente entre os produtos enzimáticos comerciais, e as diferenças entre as proporções e atividades de cada enzima podem ter um impacto na eficácia de degradação da parede celular.

A atividade das enzimas, em geral, é determinada mensurando-se a taxa de liberação de açúcares redutores em substratos purificados, expressa em quantidade de enzima necessária para liberar os açucares reduzidos por unidade de tempo (BEAUCHEMIN et al., 2003). 
Atualmente, existe um número limitado de produtos enzimáticos para ruminantes, e estes, muitas vezes, apresentam grande variabilidade nos efeitos desejados, dependendo da situação em que são testados. Portanto, pesquisas ainda são importantes para diminuir a variabilidade de resposta.

Ainda, como os gastos com alimentação representam a maior proporção dos custos totais de produção da pecuária, maximizar a utilização dos nutrientes é essencial para manter a sustentabilidade do sistema. Desta forma, um aumento na quantidade de enzimas disponíveis no ambiente ruminal poderia potencializar as enzimas endógenas especificas produzidas pelos microrganismos ruminais e contribuir, portanto, na melhora da digestibilidade dos nutrientes das dietas.

\subsection{Justificativa}

A busca por caminhos alternativos que aumentem a produtividade animal e melhorem a eficiência econômica constitui-se uma saída a curto prazo para a pecuária de corte nacional, onde o produtor é tido como um "tomador" de preços, não tendo poder de decisão sobre o valor comercial dos insumos comprados ou dos produtos acabados vendidos.

Sabe-se que a utilização de enzimas melhora o desempenho animal por aumentar a digestibilidade dos alimentos, com uma maior parte os nutrientes tornando-se disponível ao metabolismo e produção animal.

Vários estudos, utilizando aditivos enzimáticos em dietas para ruminantes, têm relatado melhora na digestibilidade da fibra (JUDKINS e STOBART, 1988; BEAUCHEMIN et al., 1995; BEAUCHEMIN et al., 1997; RODE et al., 1999; CRUYWAGEN e GOOSEN, 2004). 
Outros relatos, porém, não demonstraram tal eficácia, sob condições experimentais peculiares (VICINI et al., 2003; McALLISTER et al., 1999; YANG et al., 2000).

Apesar de constatada a melhora da digestibilidade dos alimentos em ruminantes, o modo de ação dos complexos enzimáticos ainda não está definido (FIRKINS et al., 1990), visto que as condições de aplicação desta tecnologia variam consideravelmente e os resultados nem sempre são positivos. Portanto, está claro que enzimas exógenas podem ser eficazes para ruminantes, mas é importante determinar as condições mais prováveis de se obter respostas favoráveis.

Além disso, com o aumento do número de consumidores preocupados com o uso de promotores de crescimento e antibióticos para produção animal, não há dúvidas de que as enzimas terão um papel muito importante no futuro (BEAUCHEMIN et al., 2003).

\subsection{Objetivo}

Determinar a dosagem ótima de utilização de produto enzimático comercial, contendo amilase, celulase, fitase, xilanase, betaglucanase, pectinase e protease, em ovinos confinados, avaliando:

- Desempenho dos animais;

- Digestibilidade da matéria seca (MS), fibra em detergente neutro (FDN), fibra em detergente ácido (FDA), proteína bruta (PB), extrato etéreo (EE), nutrientes digestíveis totais (NDT) e amido;

- Fósforo e glicose plasmáticos;

- Protozoários ciliados e pH ruminais; 
- Características da carcaça e da carne. 


\section{REVISÃO DA LITERATURA}

Produtos enzimáticos, na alimentação de ruminantes, são extratos concentrados resultantes da fermentação bacteriana (principalmente Bacillus spp.) ou fúngica (principalmente Trichoderma longibrachiatum, Aspergillus niger, $A$. oryzae), que têm atividades enzimáticas específicas. Genericamente, são misturas de diferentes celulases e xilanases que foram, originalmente, produzidas e comercializadas para outros fins. Além de enzimas fibrolíticas, estes produtos também apresentam atividades enzimáticas secundárias, como amilases, proteases e pectinases (BEAUCHEMIN et al., 2003). Atualmente, existem produtos específicos elaborados para degradação de outros nutrientes, que não as fibras.

A utilização de enzimas melhora a digestibilidade e aumenta da taxa de passagem dos alimentos, o que pode causar uma maior ingestão de matéria seca (FENG et al., 1996). Alguns autores consideram ainda uma melhora na palatabilidade/aceitabilidade dos alimentos pelos animais (BEAUCHEMIN et al., 1999).

Os complexos enzimáticos atuam também diminuindo a viscosidade da digesta no duodeno, o que contribui para maior digestão e absorção de nutrientes pelos animais (BEDFORD et al., 1991). Hristov et al. (2000) observaram, além de um aumento de $30 \%$ na atividade da xilanase no intestino, redução da viscosidade do conteúdo quando fornecidos altos níveis de enzimas.

Pritchard et al. (1996) verificaram que a utilização de celulase e xilanase exógenas melhorou o ganho de peso, consumo e eficiência alimentar de bovinos de corte recebendo dietas a base de feno de gramíneas.

Contrariamente, Kung et al. (2000) não observaram alteração na ingestão de matéria seca, digestibilidade "in vitro" e produção de ácidos graxos de cadeia curta 
(AGCC) "in vivo", mas notaram melhora em relação à produção de leite, o que denota uma mudança positiva em termos de fermentação ruminal, que não pode ser explicada.

Percebe-se, pelo exposto, que a utilização de enzimas fibrolíticas na alimentação de ruminantes não é de interesse universal, uma vez que apresenta efeito somente em certos casos (BEAUCHEMIN, 1997).

\subsection{Variabilidade de resposta}

Um dos principais entraves para a realização de pesquisas nesta área é a inconsistência de resultados. Como existe uma variedade de produtos enzimáticos e diversas condições experimentais, as respostas observadas para utilização de enzimas alimentares para ruminantes são muito variáveis. Esta variação pode ser atribuída nas condições às quais a energia não é o nutriente limitante, pela diferença de atividade e características das enzimas suplementadas, por uma super ou subdosagem da atividade enzimática e pelo método inapropriado de fornecimento da enzima para o animal (BEAUCHEMIN et al., 2003).

Ainda, Colombatto et al. (2003) citaram que essa variabilidade de resposta encontrada quando do uso de enzimas para ruminantes pode ser devido à proporção de forragem na dieta, $\mathrm{pH}$ do rúmen e tempo de retenção do alimento no rúmen. A composição e os componentes das dietas às quais as enzimas serão adicionadas também influenciam sua eficácia (CRUYWAGEN e GOOSEN, 2004).

Em observância a este fato, Beauchemin et al. (1997) relataram que misturas enzimáticas (celulase e xilanase) adicionadas em dietas à base de cevada, oferecidas à novilhos, melhoraram a eficiência alimentar dos animais. Entretanto, 
quando avaliadas em dietas à base de milho, não tiveram efeito, indicando a importância da utilização de combinações enzimáticas específicas para cada substrato alimentar. Os autores salientam que, como o grão da cevada apresenta uma camada protetora, a melhora na digestibilidade do amido e proteína do endosperma, devido à aplicação de enzimas, é muito mais evidente.

McAllister et al. (1999) resumiram os pontos mais importantes que determinam a eficiência da suplementação enzimática, considerando o local de atuação das enzimas: 1. se a atividade das enzimas no alimento, anteriormente à ingestão deste, é importante, fatores como uniformidade da aplicação, temperatura ambiente e a duração do tempo de exposição do alimento à enzima são essenciais; 2. quando as enzimas exercem seus efeitos no rúmen, a estabilidade das enzimas e as enzimas microbianas complementares, além do tempo de retenção no rúmen, podem ser os fatores críticos; 3. e, por fim, se as enzimas exercem seus efeitos no intestino delgado, a resistência destas ao ácido clorídrico, pepsina e proteases é que deve ser levada em consideração.

Parece que a resposta para a suplementação enzimática é altamente dependente do nível de volumoso; quanto maior sua proporção na dieta, maior a probabilidade de observar resposta positiva sobre o desempenho (VICINI et al., 2003).

A variabilidade das respostas em trabalhos desta natureza é tão expressiva que Beauchemin et al. (2003), avaliando 20 estudos e 41 tratamentos, observaram que o aumento médio, com o respectivo desvio-padrão, para a ingestão de matéria seca e produção diária de leite foi de 1,0 \pm 1,3 e 1,1 \pm 1,5 kg/dia, respectivamente, quando os alimentos receberam enzimas exógenas. Conclui-se, portanto, que as respostas geralmente são positivas, porém, com variação exacerbada. 
É importante salientar que é muito difícil avaliar a influência de complexos enzimáticos sobre o desempenho de animais. Na comparação entre dois produtos enzimáticos diferentes, mas com atividades de celulase e xilanase muito semelhantes, nas dietas de vacas em lactação, Kung et al. (2000) observaram que apenas um resultou em aumento na produção de leite. Este resultado indica que pode não ser possível predizer o potencial de aumento da digestão da parede celular no rúmen, usando enzimas exógenas, baseado somente em sua caracterização bioquímica.

Os autores acrescentam que esta observação não é surpresa, uma vez que as atividades enzimáticas são mensuradas em modelos de substratos que não representam a complexidade da parede celular das plantas. Portanto, conhecer as unidades de atividade enzimática é importante para o controle da qualidade e garantia do produto para o cliente, mas isso tem pequena relação com a eficácia do produto como aditivo para alimentação de ruminantes.

A adequada descrição das atividades enzimáticas presentes nos produtos utilizados na alimentação de ruminantes continua sendo um grande desafio no desenvolvimento de enzimas comerciais (McALLISTER et al., 1999). E também, as pesquisas frequentemente dão foco somente na enzima principal dos produtos, sem considerar as outras atividades secundárias que possam estar presentes. Considerando que estas atividades podem ser específicas para determinadas ligações que limitam a digestão da parede celular (como, por exemplo, complexos lignina/carboidrato), as enzimas secundárias são tão importantes como as principais na determinação da eficiência geral das preparações para ruminantes. 


\subsubsection{Níveis de enzimas}

Os níveis de enzimas normalmente utilizados como aditivos para a alimentação de ruminantes variam de 0,5 a $2 \mathrm{mg} / \mathrm{g}(\mathrm{ou} \mathrm{g} / \mathrm{kg})$ da dieta total, em MS, como salientado por Beauchemin et al. (2003). Porém, estes níveis são dependentes das características específicas de cada produto, como tipo e atividade das enzimas presentes.

A dosagem é um dos principais fatores responsáveis pela ineficácia dos produtos enzimáticos. Subdosagens são insuficientes em provocar alguma melhora da digestibilidade, sendo que superdosagens, além de maiores custos de produção, podem competir com os microrganismos pelos mesmos sítios de adesão do substrato, ou então liberar fatores antinutricionais tóxicos.

Wallace et al. (2001) utilizaram seis produtos enzimáticos diferentes para determinar a relação entre as atividades enzimáticas e a produção de gás in vitro, utilizando silagens de capim ou milho. Uma correlação positiva foi encontrada entre a atividade da celulase e produção de gás para a silagem de capim. Em estudo complementar, foi observado que preparações com atividade relativamente alta de celulase aumentou a taxa de produção de gás para a silagem de milho. Entretanto, com produtos apresentando atividade relativamente alta de xilanase, não foi obtido o mesmo efeito quando a atividade da glucanase era baixa. Isso evidencia que é possível melhorar a eficácia das preparações enzimáticas aumentando-se a atividade da celulase. No entanto, os níveis de enzimas utilizados nestes estudos foram 20 a 40 vezes superiores aos níveis normalmente utilizados como aditivos para a alimentação de ruminantes.

É interessante mencionar que os níveis utilizados in vitro, em geral, são valores muito acima dos normalmente empregados na prática (in vivo). Portanto, 
deve-se ter muito cuidado na extrapolação dos resultados quando este fato é observado.

Lewis et al. (1999) trabalharam com vacas Holandesas no início da lactação, alimentadas com feno e silagem de alfafa e $60 \%$ de concentrado a base de cevada. A mistura enzimática continha 1.800 unidades de carboximetilcelulase/mL e 7.300 unidades de xilanase $/ \mathrm{mL}$. Os animais foram aleatoriamente distribuídas nos tratamentos 0 (controle); 1,25; 2,5; e 5,0 mL de mistura/kg de MS da forragem. Como resultado, a IMS foi maior para os animais que receberam enzima. Já a produção de leite foi maior somente para o nível intermediário de enzima; consequentemente, a eficiência de produção do nível intermediário $(2,5 \mathrm{~mL} / \mathrm{kg})$ foi superior aos outros níveis, mas foi igual ao controle.

Os autores citam que a melhoria da resposta para vacas em lactação consumindo um nível intermediário de enzimas foi interessante, mas não pôde ser explicada pelos dados da literatura. Portanto, esta resposta indica a necessidade da determinação da concentração ideal de adição das enzimas, considerando os alimentos utilizados.

Da mesma forma, Beauchemin et al. (1995) utilizaram três dietas, compostas por $97 \%$ de feno de alfafa, $91 \%$ de feno timothy (Phleum pratense) ou $91 \%$ de silagem de cevada oferecidas a bezerros cruzados. Aplicaram xilanase e celulase nas proporções (0) 0, 0; (1) 1.000, 40; (2) 2.000, 80; (3) 3.900, 156; (4) 7.900, 316 e (5) 15.800, $632 \mathrm{IU}, \mathrm{FPU} / \mathrm{kg}$ de MS da forragem, respectivamente. A relação específica xilanase:celulase foi mantida em 1 UI:0,04 FPU. Para o feno de alfafa, aumentou-se o GPD somente com os níveis 1, 2 e 3. Altos níveis não foram eficientes em promover melhora dos parâmetros analisados. Para o feno Timothy, o maior nível de enzima (6) melhorou o GPD em 36\% devido ao aumento de 17\% na 
digestibilidade da fibra. Esta melhora não foi acompanhada de mudança na IMS, o que melhorou a conversão alimentar em $20 \%$. Para os demais níveis, não se observou aumento do GPD. Para a silagem de cevada, a adição de enzimas não teve efeito no GPD e conversão alimentar. Os autores comentam que a relação entre a concentração enzimática e a resposta animal não foi linear, e foi diferente para leguminosa e gramínea.

Pelas informações apresentadas, percebe-se que a determinação dos níveis enzimáticos é totalmente dependente do tipo e concentração da atividade das enzimas presentes nos produtos. Portanto, há uma variação considerável, que dificulta a comparação entre os trabalhos.

\subsubsection{Teor de umidade do alimento}

Beauchemin et al. (1995) encontraram efeito da aplicação de enzimas sobre alimentos secos (fenos de alfafa e timothy), mas não em alimento úmido (silagem de cevada). Porém, a razão das diferenças de resposta à aplicação enzimática entre os tipos de forragens não ficou clara, uma vez que, para a silagem, as enzimas foram aplicadas pouco antes da alimentação, e para os fenos, logo após estes terem sido picados. Portanto, esta variação pode ter sido devida aos diferentes tipos de forrageiras ou ao método de aplicação. A falta de resposta quando do uso de silagem de cevada indica que o teor de umidade dos alimentos é importante e, possivelmente, afeta a ligação enzima:substrato.

Outra possível explicação seria pelo fato de que dietas mais fibrosas, como no caso dos fenos, têm uma maior quantidade de substrato disponível para atuação das enzimas fibrolíticas, ocorrendo maior liberação de carboidratos solúveis, com 
conseqüente aumento da digestibilidade da energia, como mencionado por Martins et al. (2006). Estes autores, avaliando silagem de milho ou feno de tifton 85 tratados ou não com enzima, encontraram aumento significativo na digestibilidade (de 31,49 para $39,20 \%$, na ausência ou presença do produto, respectivamente) quando a enzima foi adicionada somente ao feno.

Em alimentos úmidos, como as silagens, doses maiores de produtos enzimáticos parecem ser mais eficientes, conforme trabalho realizado por Beauchemin e Rode (1996) com silagem de milho, mostrando que o melhor desempenho animal se deu na maior dose de enzima (celulase e xilanase). Portanto, a aplicação de produtos enzimáticos em alimentos secos tem apresentado melhores resultados.

Entretanto, para que haja hidrólise dos açúcares solúveis, é fundamental presença de água no meio no qual acontece a reação. McAllister et al. (2001) citaram que a liberação destes açúcares nos alimento denominados secos sugere que o conteúdo aquoso é suficiente para promover hidrólise.

\subsubsection{Métodos de aplicação das enzimas sobre o alimento}

Existem diversas maneiras de fornecimento das enzimas para os animais, e esse fator exerce grande influência sobre a eficácia do produto nos alimentos. Os trabalhos relatam aplicações de preparações enzimáticas diretamente no rúmen, sobre a dieta total ou sobre parte da dieta (volumoso ou concentrado). Ainda, estes produtos podem ser adicionados secos ou na forma líquida. O tempo de atuação das enzimas sobre o alimento, anteriormente à ingestão, também parece ser importante. 
Quando as enzimas são introduzidas diretamente no rúmen, parece não haver efeito destas sobre a digestibilidade dos alimentos, como constatado por McAllister et al. (1999). A hipótese para explicar o ocorrido baseia-se no fato de que a solução enzimática adicionada diretamente no rúmen passa, juntamente à fração líquida, por este compartimento, não tendo a oportunidade de hidrolisar a parede celular das plantas. Desta forma, supõe-se que o contato das enzimas com o substrato antes da ingestão do alimento é importante para se atingir benefícios desta suplementação.

Da mesma forma, a introdução de preparação com celulase e xilanase no rúmen reduziu a IMS e a digestibilidade do alimento (forragens e cevada) oferecido a novilhos de corte, quando comparada com a aplicação sobre o alimento (LEWIS et al., 1996).

Michal et al. (1996), trabalhando com produto enzimático em feno de alfafa, concluíram que a melhor forma de aplicação é momentos antes da dieta ser oferecida ao animal.

A utilização de produto enzimático diluído em água e aplicado ao alimento 24 horas antes do fornecimento aos animais é eficiente em alterar a composição química do volumoso, diminuindo os teores de FDN e FDA, segundo Krause et al. (1998).

\subsubsection{Proporção volumoso:concentrado da dieta}

Como mencionado anteriormente, parece que quanto maior a proporção de volumoso na dieta, maior a probabilidade de observar resposta positiva sobre o desempenho (VICINI et al., 2003). 
Judkins and Stobart (1988) utilizaram nove cordeiros canulados no rúmen (peso inicial de 28,6 kg), na condução de dois experimentos, para avaliar o efeito da adição de níveis de enzimas na dieta, sendo 0, 22 e $35 \mathrm{~g} /$ dia de uma preparação com enzimas fúngicas. Os animais foram alimentados com feno de alfafa e milho moído.

Para o experimento 1, utilizaram-se $10 \%$ de grãos na dieta, sendo esta oferecida na proporção de $2,1 \%$ do PV; para o experimento 2, a dieta continha $25 \%$ de grãos, oferecida na quantidade de $2,7 \%$ do PV. Foi verificado, somente para a dieta com $10 \%$ de grãos de milho, uma digestibilidade da parede celular maior $(p<0,05)$ para o tratamento que recebeu $35 \mathrm{~g}$ de enzima/dia $(49,8 \%)$, mediante aos tratamentos com 0 e $22 \mathrm{~g} / \mathrm{dia}(45,7$ e $42,9 \%$, respectivamente).

Quando a dieta apresentou $25 \%$ de grãos de milho (experimento 2), este efeito foi anulado $(44,0 ; 47,0$ e $43,1 \%$ para os tratamentos com 0,22 e $35 \mathrm{~g}$ de enzima/dia, respectivamente). É importante destacar que os autores não caracterizaram o produto enzimático usado e também não fizeram comparações entre os experimentos.

Entretanto, para vacas de leite e bovinos em terminação, tem-se que, em dietas de alto-grão, as enzimas atuam ajudando a superar a depressão da digestão da fibra que ocorre em baixo pH, segundo Beauchemin et al. (1994b).

\subsection{Utilização de amilase}

Pesquisas na área de suplementação de enzimas para ruminantes têm focado, principalmente, nas enzimas fibrolíticas, enquanto que as atividades envolvidas nos processos de digestão do amido têm sido ignoradas. Porém, quando 
o amido representa o principal componente em dietas de animais de alta produção, como em confinamento, o uso de enzimas que manipulem sua digestão no rúmen poderá promover aumento da produtividade (TRICARICO et al., 2008). Segundo Huntington (1997), a digestão ruminal do amido é um dos fatores mais importantes na determinação do desempenho de ruminantes alimentados com dietas de alto concentrado.

Entretanto, os principais entraves para a utilização de enzimas amilolíticas são decorrentes da percepção de que 1. a digestão do amido pelos ruminantes é extensa e geralmente não limita a produção da mesma forma que a digestão incompleta ou lenta da fibra; e 2. a rápida digestão de quantidades excessivas de amido pode levar à acidose ruminal, o que representa um risco em potencial para a inclusão de amilases exógenas na dieta de ruminantes (TRICARICO et al., 2008).

Portanto, a suplementação exógena de amilase poderia ser empregada para diminuir as variações inexplicáveis da degradação ruminal de amido em fontes ricas deste componente na dieta. Teoricamente, a suplementação com a-amilase aumenta a disponibilidade dos produtos da hidrólise do amido no rúmen, alterando, consequentemente, os processos de fermentação ruminal.

Rojo et al. (2005) estudaram os efeitos da a-amilase (Bacillus licheniformis) e da glicoamilase (Aspergillus niger) sobre a ingestão de alimentos, digestibilidade e fermentação ruminal em ovinos Suffolk. Para tanto, utilizaram ambas as enzimas nas proporções 0 (controle); 1,45 e 2,9 g/kg de MS, em dieta contendo $70 \%$ de grãos de sorgo, $17 \%$ de palha de aveia, $1 \%$ de melaço, $0,2 \%$ de uréia e $0,1 \%$ de mistura mineral.

Como resultado, para a $\alpha$-amilase, a ingestão de MS $(1,408 ; 1,341$ e 1,333 $\mathrm{kg} / \mathrm{dia}$ para os níveis $0 ; 1,45$ e 2,9 $\mathrm{g} / \mathrm{kg}$, respectivamente), MO e amido declinaram 
linearmente com o aumento do nível desta enzima, sendo que a digestão ruminal do amido e a digestão, no trato total, da MS (68,5; 69,4 e 72,1\%), MO (70,7; 71,8 e $74,4 \%)$ e do amido $(94,8 ; 95,2 ; 97,2 \%)$ tiveram um efeito quadrático, assim como o $\mathrm{pH}$ ruminal. O total de ácidos graxos de cadeia curta diminuiu linearmente, enquanto que o número de protozoários (490, 373 e $250 \times 10^{3}$ células $/ \mathrm{mL}$ ) diminuiu até o nível intermediário, apresentando efeito quadrático. A a-amilase de Bacillus licheniformis apresentou maior atividade enzimática em comparação à glicoamilase de Aspergillus niger. Mendoza et al. (1993) citaram que presença de protozoários ciliados reduz a taxa e extensão da digestão ruminal do amido.

Para a glicoamilase, observou-se que a ingestão de MS $(1,370 ; 1,415 ; 1,300$ $\mathrm{kg} / \mathrm{dia}$ para os níveis $0 ; 1,45$ e 2,9 g/kg, respectivamente), MO e amido, não foi afetada pelo uso de enzima, e a digestibilidade no trato total do amido declinou linearmente, conforme se aumentou o nível da enzima. Os protozoários ruminais (163, 351 e $277 \times 10^{3}$ células $\left./ \mathrm{mL}\right)$ aumentaram linearmente. Os autores mencionam que as condições ruminais (pressão osmótica, $\mathrm{pH}$ e taxa de diluição) que estimularam o crescimento da população de protozoários em dietas de alto grão não ficaram claras. Portanto, os autores concluíram que somente a amilase produzida por Bacillus licheniformis aumenta a digestão ruminal do amido, com potencial para ser usada em ruminantes alimentados com dietas de alto grão com baixa digestibilidade.

É notável que os parâmetros envolvidos no desempenho dos animais (ingestão de alimentos, digestibilidade dos nutrientes, concentração de protozoários ciliados ruminais, entre outros) não são melhorados com a adição de qualquer enzima. Portanto, pode-se supor que isso seja reflexo de uma especificidade enzima:substrato que, por sua vez, sobre a influência de muitos outros fatores. Além 
disso, enzimas com a mesma atividade apresentam modos de ação distintos, que precisam ser estudados.

\subsection{Utilização de fitase}

A fitase é uma enzima muito utilizada na nutrição de não-ruminantes e que pode ser adaptada à dieta de ruminantes. A maior parte do fósforo nos grãos está na forma fítica e, embora o rúmen tenha uma grande variedade de fitases microbianas (NAKASHIMA et al., 2007) e muita habilidade em utilizar o fósforo do fitato (MORSE et al., 1992), pouco se sabe sobre a disponibilidade verdadeira do fósforo nos alimentos fornecidos a ruminantes, sendo que, no estudo conduzido por Bravo et al. (2003), os autores apresentaram valor médio de absorção de fósforo ingerido de $72 \%$. Portanto, o uso de fitase na alimentação de ruminantes poderia aumentar a disponibilidade de fósforo para absorção.

\subsection{Avaliação de produtos enzimáticos na espécie ovina}

Parece que os ovinos apresentam resposta diferente dos bovinos em relação à suplementação enzimática. Desta foram, é necessário cuidado ao se utilizar a espécie ovina como unidade experimental para experimentos desta natureza, visando extrapolar os dados obtidos para bovinos, e vice-versa.

Como exemplo, Yang et al. (2000) avaliaram produto enzimático, com alta atividade de xilanase e baixa de celulase, aplicado sobre a dieta total (DT) ou somente ao concentrado (CONC) em dieta com $24 \%$ de silagem de milho, $14 \%$ de 
feno de alfafa e $62 \%$ de concentrado a base de cevada, oferecida para vacas de leite e ovinos. Para a espécie bovina, a IMS (média de 19,8 kg/dia) não foi afetada pela suplementação enzimática. Mas a produção de leite foi maior para as vacas do tratamento CONC $(37,4 \mathrm{~L} / \mathrm{dia})$ frente às vacas do controle $(35,3)$ e DT $(35,2)$. A digestibilidade da MS no trato total seguiu a mesma tendência, sendo maior para as vacas do tratamento CONC $(66,6 \%)$ que para as vacas do controle $(63,9)$ e DT $(65,7)$.

Entretanto, para o experimento com ovinos, a digestibilidade das dietas não foi afetada pela suplementação enzimática, sendo 75,$6 ; 74,8$ e $74,5 \%$ para os tratamentos controle, DT e CONC, respectivamente. Os autores citaram, portanto, que o método de aplicação das enzimas deve ser considerado para maximizar seus benefícios sobre as dietas e que, quando a digestão do alimento é naturalmente alta, não há melhora na digestibilidade da MS.

Aliando os dados do trabalho citado acima com os de Judkins \& Stobart (1988), que observaram melhora da digestão da fibra em cordeiros alimentados com $90 \%$ feno de alfafa e $10 \%$ de milho moído, suplementados com enzima, mas este efeito foi anulado quando a dieta passou a ter $25 \%$ de milho, há indicativo de que os produtos enzimáticos, para a espécie ovina, são eficazes somente para dietas com alto volumoso (YANG et al., 2000).

Porém, em dietas de alto concentrado, que apresentam baixa digestibilidade, pode-se ter efeito das enzimas sobre este parâmetro, como verificado por Rojo et al. (2005), em ovinos alimentados com sorgo.

Portanto, tem-se que ovinos não representaram um modelo adequado para avaliar os efeitos de enzimas exógenas sobre a digestibilidade dos alimentos em gado de leite (YANG et al., 2000) e, muito provavelmente, no de corte. 


\section{MATERIAL E MÉTODOS}

\subsection{Local, animais e alimentação}

O experimento foi conduzido no Departamento de Zootecnia da Faculdade de Zootecnia e Engenharia de Alimentos (FZEA) da Universidade de São Paulo (USP) (figura 1), localizado no município de Pirassununga-SP.

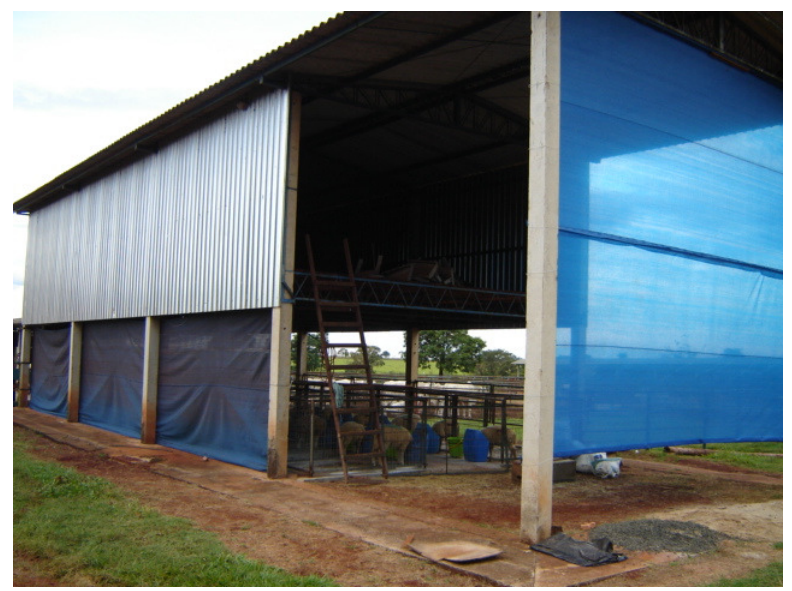

Figura 1. Galpão experimental de ovinocultura do Departamento de Zootecnia da FZEA-USP.

O período experimental teve duração de 61 dias, sendo sete para adaptação dos animais à dieta, 42 para coleta dos dados de desempenho (divididos em três períodos de 14 dias) e 12 para coleta dos materiais necessários para cálculo da digestibilidade dos nutrientes e do amido.

Foram utilizados 24 animais machos cruzados lle de France, com aproximadamente 80 dias de idade e 22,27 $\pm 1,85 \mathrm{~kg}$ de peso inicial, mantidos em baias individuais cobertas (figura 2), divididos em quatro tratamentos, com seis repetições cada, referentes às diferentes dosagens de enzimas:

- 0,0 (controle);

- $0,3 \mathrm{~g} / \mathrm{Kg}$ de MS $(0,03 \%)$; 
- $0,9 \mathrm{~g} / \mathrm{Kg}$ de $\mathrm{MS}(0,09 \%)$;

- $2,7 \mathrm{~g} / \mathrm{Kg}$ de MS $(0,27 \%)$.

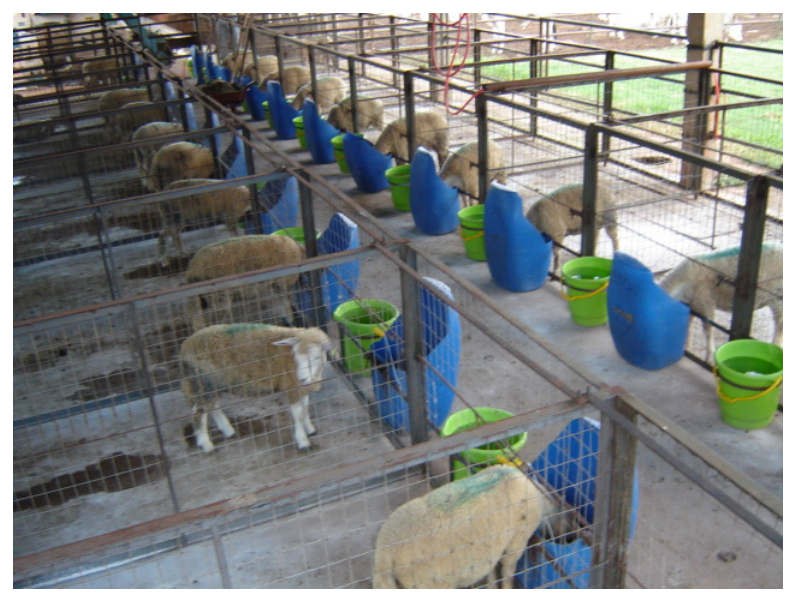

Figura 2. Cordeiros cruzados lle de France utilizados no experimento.

No período de digestibilidade dos nutrientes e do amido, que se estendeu por 12 dias, sendo sete de adaptação dos cordeiros à instalação e aos arreios, os animais foram transferidos para um galpão coberto, com baias individuais suspensas (figura 3).

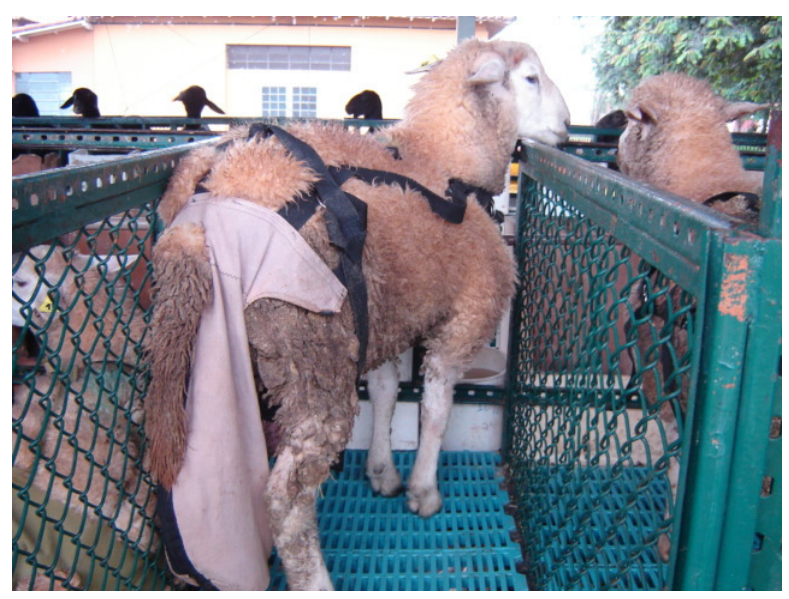

Figura 3. Baias suspensas e arreios utilizados no período de digestibilidade.

A alimentação foi fornecida diariamente pela manhã, sendo o ajuste do alimento calculado para manter cerca de 10\% de sobra, evitando que a seleção da dieta influenciasse os resultados. $\mathrm{O}$ fornecimento de água foi à vontade. 
A composição da dieta, formulada para atender as exigências de cordeiros segundo NRC (2007) e avaliada através do programa SRNS (Small Ruminant Nutrition System, Cornell University), está demonstrada na tabela 1.

Tabela 1. Composição percentual e química das dietas experimentais.

\begin{tabular}{lcccc}
\hline \multirow{2}{*}{ Ingredientes (\%) } & \multicolumn{4}{c}{ Tratamentos (g enzima/kg MS) } \\
\cline { 2 - 5 } & 0,0 & 0,3 & 0,9 & 2,7 \\
\hline Feno de Coast cross & 13,00 & 13,00 & 13,00 & 13,00 \\
Milho grão seco & 67,90 & 67,87 & 67,81 & 67,63 \\
Farelo de soja 45\% & 17,00 & 17,00 & 17,00 & 17,00 \\
Uréia & 1,60 & 1,60 & 1,60 & 1,60 \\
Sal mineral & 0,50 & 0,50 & 0,50 & 0,50 \\
Enzima & 0,00 & 0,03 & 0,09 & 0,27 \\
\hline Nutrientes observados (\%) & & & & \\
NDT & 78,96 & 79,03 & 78,39 & 75,89 \\
PB & 21,92 & 20,52 & 23,28 & 22,08 \\
FDN & 23,56 & 27,26 & 24,82 & 28,39 \\
FDA & 8,88 & 12,63 & 10,91 & 13,64 \\
\hline NDT:nutron
\end{tabular}

NDT: nutrientes digestíveis totais; PB: proteína bruta; PDR: proteína degradável no rúmen; FDN: fibra em detergente neutro; FDA: fibra em detergente ácido.

O complexo enzimático utilizado foi o produto comercial Allzyme SSF ${ }^{\circledR}$ (Alltech Biotechnology), contendo $30 \mathrm{u} / \mathrm{g}$ de amilase, $40 \mathrm{u} / \mathrm{g}$ de celulase, $300 \mathrm{u} / \mathrm{g}$ de fitase, $100 \mathrm{u} / \mathrm{g}$ de xilanase, $200 \mathrm{u} / \mathrm{g}$ de betaglucanase, $4000 \mathrm{u} / \mathrm{g}$ de pectinase e $700 \mathrm{u} / \mathrm{g}$ de protease, conforme especificações do fabricante. O produto foi adicionado, nas proporções de cada tratamento, no momento da mistura do concentrado. As respectivas quantidades de enzimas foram adicionadas retirando-se as mesmas proporções de milho grão seco. 


\subsection{Desempenho animal}

Os animais foram pesados a cada 14 dias, após jejum completo de 16 horas. O alimento e a sobra foram pesados diariamente para cálculo da ingestão de matéria seca diária (IMS), ganho de peso diário (GPD) e conversão alimentar (CA).

\subsection{Digestibilidade aparente dos nutrientes e do amido}

Utilizou-se o método direto de estimativa de digestibilidade, por meio da coleta total de fezes. Para tal, foram realizadas coletas de alimentos, sobras e fezes (através de bolsa coletora) nos últimos cinco dias do período experimental (figura 4), evitando uma possível influência do estresse sobre os dados de desempenho animal. As amostras foram mantidas a $-20^{\circ} \mathrm{C}$ para análises posteriores.

As determinações de matéria seca do alimento, da sobra e das fezes seguiram as recomendações da AOAC (1990). Após o descongelamento, as amostras passaram por um processo de pré-secagem, sendo submetidas à pesagem em bandejas com pesos pré-determinados e direcionadas para a estufa à 55ํㅡ, com ventilação forçada e renovação de ar, por 72 horas. Em seguida, foram moídas em peneira com crivos de $1 \mathrm{~mm}$. Posteriormente, foram levadas para estufa à $105^{\circ} \mathrm{C}$ por 12 horas, para obtenção da matéria seca total do alimento, utilizada nos cálculos. 

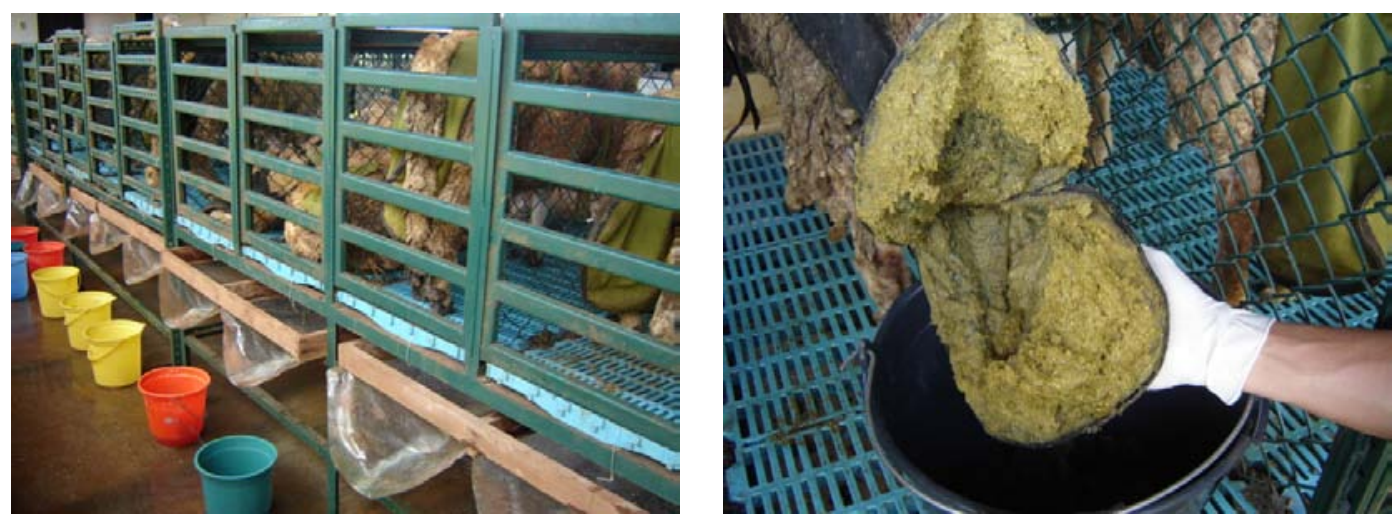

Figura 4. Gaiolas e arreios para coleta total de fezes.

A digestibilidade aparente da matéria seca (MS) foi calculada através da fórmula:

$$
C D_{a p}=\frac{(\text { ingerido }- \text { excretado }) \times 100}{\text { ingerido }}
$$

Onde: $\mathrm{CD}_{\mathrm{ap}}$ : coeficiente de digestibilidade aparente (\%);

Ingerido: média da quantidade de alimento ingerido (oferecido - sobra) (kg/dia);

Excretado: média da quantidade de fezes excretada ( $\mathrm{kg} / \mathrm{dia})$.

Para o cálculo da digestibilidade dos nutrientes (FDN, FDA, PB, EE e NDT) e do amido, utilizou-se a mesma fórmula, multiplicando-se o alimento ingerido, a sobra e as fezes pelas respectivas proporções de cada variável, obtidas em laboratório.

As análises de matéria seca (MS), proteína (PB) e extrato etéreo (EE) do alimento, sobra e fezes foram calculadas de acordo AOAC (1990); as determinações da fibra em detergente neutro (FDN) e fibra em detergente ácido (FDA), seguiram as recomendações de Van Soest et al. (1991), a partir das amostras secas à 55ㄷ․ O NDT foi calculado segundo Weiss et al. (1992). Para este cálculo, realizaram-se análises adicionais de lignina (L) (VAN SOEST et al., 1991), matéria mineral (MM), 
nitrogênio indigestível em detergente neutro (NIDN) e nitrogênio indigestível em detergente ácido (NIDA) (AOAC, 1990).

\subsubsection{Análise de amido}

Das amostras secas à $55^{\circ} \mathrm{C}$, retirou-se uma subamostra para análise de amido. Posteriormente, essas foram enviadas para o laboratório, para determinação de amido segundo Hendrix (1993).

Esta determinação baseia-se na hidrólise de amido contido na amostra, após a extração dos carboidratos solúveis com sucessivas lavagens com álcool 80\%, e análise colorimétrica dos açúcares redutores (glicose), com posterior conversão do resultado para amido.

\subsection{Parâmetros sanguíneos}

Amostras de sangue foram obtidas, por punção, da veia jugular em tubos vacuntainers com anticoagulantes (figura 5). Estas foram centrifugadas, no máximo 2 horas após a coleta, para separação do plasma e, a seguir, refrigeradas a $-20^{\circ} \mathrm{C}$ para análises posteriores. 


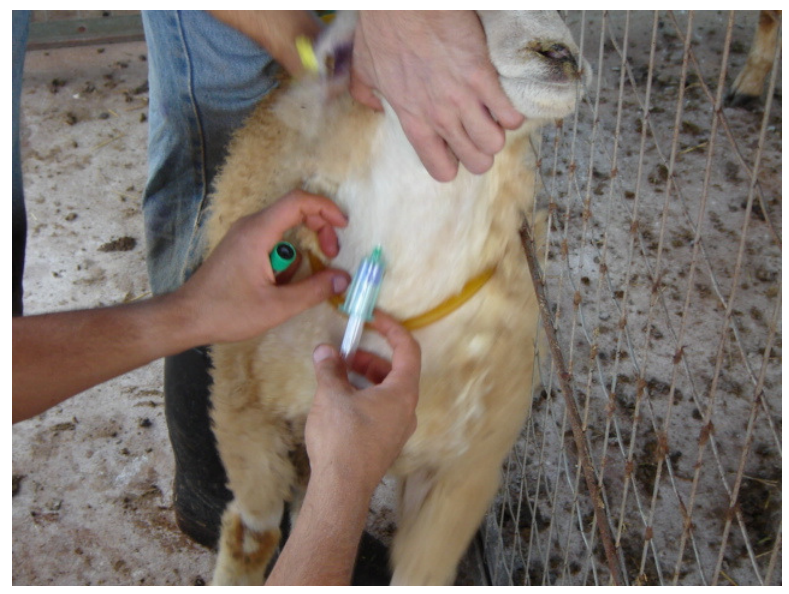

Figura 5. Coleta de sangue pela veia jugular, através de tubos vacuntainers.

\subsubsection{Fósforo}

Para a análise do fósforo, o anticoagulante utilizado foi o EDTA. O nível de fósforo foi determinado, no plasma sanguíneo, pelo kit comercial "Fósforo-UV, Liquid Stable", da Laborlab ${ }^{\circledR}$, conforme especificações do fabricante. As absorbâncias foram determinadas em espectrofotômetro. A fórmula utilizada foi:

$$
\text { Fósforo }=\frac{\text { desconhecido }}{\text { padrão }} \times 5
$$

Onde: Fósforo: concentração do mineral na amostra (mg/dL);

Desconhecido: absorbância das amostras experimentais.

\subsubsection{Glicose}

Para a análise de glicose, utilizou-se anticoagulante fluoretado. As concentrações de glicose sanguíneas foram determinadas pelo kit comercial "Glicose GOD-PAP Método Enzimático, Liquid Stable mono-reagente", da Laborlab ${ }^{\circledR}$, 
de acordo com especificações do fabricante. As leituras de absorbância foram realizadas pelo aparelho Elisa, e os cálculos de glicose plasmática (em mg/dL), feitos por software especializado (figura 6).



Figura 6. Aparelho Elisa conectado ao computador, com software especializado, para cálculo das concentrações de glicose plasmática.

\subsection{Parâmetros ruminais}

Para mensuração dos parâmetros ruminais, logo após o abate, o rúmen de cada animal foi separado, sendo realizada, posteriormente, uma incisão ventral para coleta do conteúdo ruminal e filtragem deste.

\subsubsection{Protozoários ciliados}

Uma alíquota de $10 \mathrm{~mL}$ do líquido foi destinada para identificação e contagem de gêneros de protozoários ciliados. Esta foi transferida para frascos de vidro com $10 \mathrm{~mL}$ de formaldeído a $37 \%$. As amostras permaneceram em repouso até o momento das determinações, que foram executadas de acordo com metodologia de Dehority (2003) para determinação das curvas de aparecimento dos gêneros de 
ciliados, utilizando câmara de contagem de Sedgwick-Rafter com capacidade de 1 mL. Utilizou-se microscópio ótico comum provido de retículo com área de 0,44 mm².

\section{$3.5 .2 \mathrm{pH}$}

Logo após a coleta e filtragem do conteúdo, foi realizada a mensuração do pH utilizando-se potenciômetro digital (figura 7).
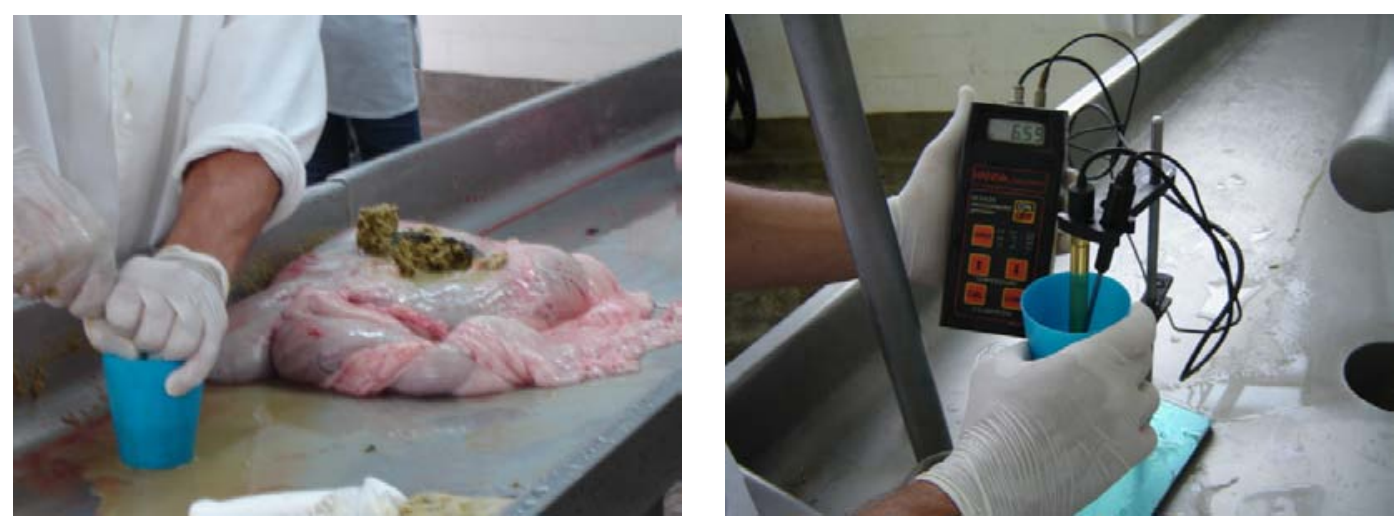

Figura 7. Incisão ventral no rúmen para a coleta de líquido ruminal e posterior determinação do pH.

\subsection{Características da carcaça e da carne}

\subsubsection{Abate e rendimento de carcaça}

O abate seguiu os padrões adotados pelo abatedouro-escola da Coordenadoria do Campus da USP de Pirassununga, utilizando-se pistola pneumática para o atordoamento, seguido da sangria, evisceração e limpeza das meias-carcaças (figura 8). Os cordeiros permaneceram em jejum com água por 16 horas antes do abate, sendo pesados momentos antes deste, obtendo-se o peso vivo ao abate (PVA, $\mathrm{kg})$ 


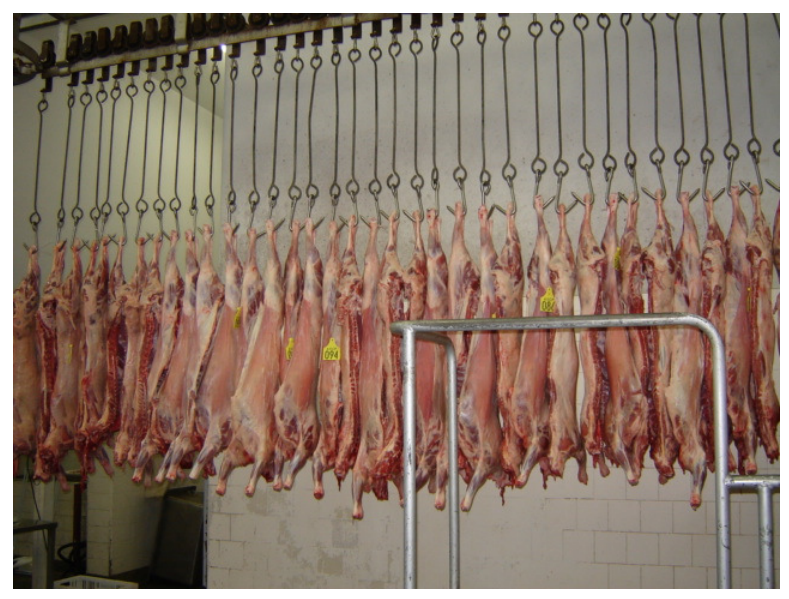

Figura 8. Carcaça limpas, dos cordeiros utilizados no experimento, para determinação dos pesos e rendimentos e demais avaliações posteriores.

Logo após o abate, foram obtidos os pesos de carcaça quente (PCQ, kg) para cálculo do rendimento de carcaça quente $(\mathrm{RCQ}(\%)=\mathrm{PCQ} / \mathrm{PVA} \times 100)$. As carcaça foram encaminhadas imediatamente a câmara fria à temperatura entre 0 e $2^{\circ} \mathrm{C}$, por 24h. Após este período, foram obtidos os pesos de carcaça fria (PCF, kg) para se determinar o rendimento de carcaça fria (RCF (\%) = PCF / PVA x 100).

\subsubsection{Temperatura e $\mathrm{pH}$}

$\mathrm{O} \mathrm{pH}$ e a temperatura $\left({ }^{\circ} \mathrm{C}\right)$ das carcaças foram mensurados após 1 e 24 horas do momento do abate. A medida foi realizada no músculo Longissimus das meiascarcaças esquerda, entre a $12^{\underline{a}}$ e $13^{a}$ costelas, utilizando-se termômetro e peagâmetro digitais, com sondas de penetração (modelo HI8314, Hanna Instruments) (figura 9). 




Figura 9. Determinação da temperatura $\left({ }^{\circ} \mathrm{C}\right)$ e pH, no músculo Longissimus, das meias-carcaças esquerda.

\subsubsection{Capacidade de retenção de água}

A CRA constitui-se em um parâmetro biofísico-químico, definido como o maior ou menor nível de fixação de água no músculo nas cadeias de actinomiosina. No momento da mastigação, um maior valor de CRA se traduz em uma sensação de maior suculência (SILVA SOBRINHO et al., 2008).

Imediatamente após o abate, $10 \mathrm{~g}$ de amostra do músculo Longissimus, de cada carcaça foi pesada e colocada em redes acondicionadas, individualmente, em sacos inflados, assegurando que as amostras não entrassem em contato com este e, posteriormente, suspensas em suporte dentro da câmara fria (figura 10). Após um período de armazenamento de 24 horas, entre 0 e $2^{\circ} \mathrm{C}$, determinou-se a CRA (\%) conforme a metodologia proposta por Honikel (1998), sendo calculada segundo a fórmula:

$$
C R A=\frac{P f}{P i} \times 100
$$


Onde: Pi: peso inicial da amostra (g);

Pf: peso final da amostra (g), após 24 horas.

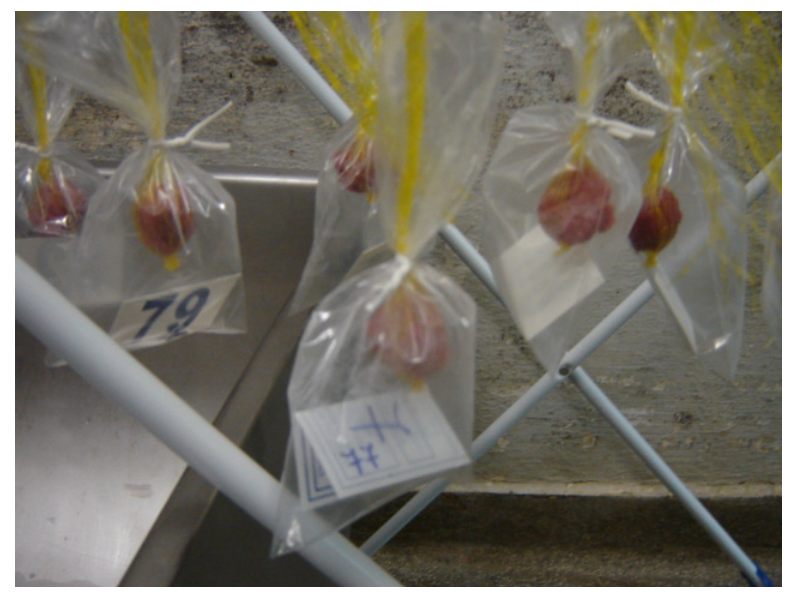

Figura 10. Amostras do músculo Longissimus, suspensas na câmara fria, dentro de redes acondicionadas em sacos inflados, evitando-se o contato das amostras com estes.

\subsection{4 Índice de compacidade}

Para o cálculo do índice de compacidade da carcaça, o peso da carcaça fria (kg) foi dividido pelo comprimento interno $(\mathrm{cm})$ da mesma, que é determinada pela distância máxima entre a sínfese ísquio-pubiana e a primeira costela (BUENO et al., 2000). O valor encontrado determina uma maior ou menor deposição de tecidos por unidade de comprimento da carcaça (figura 11). 


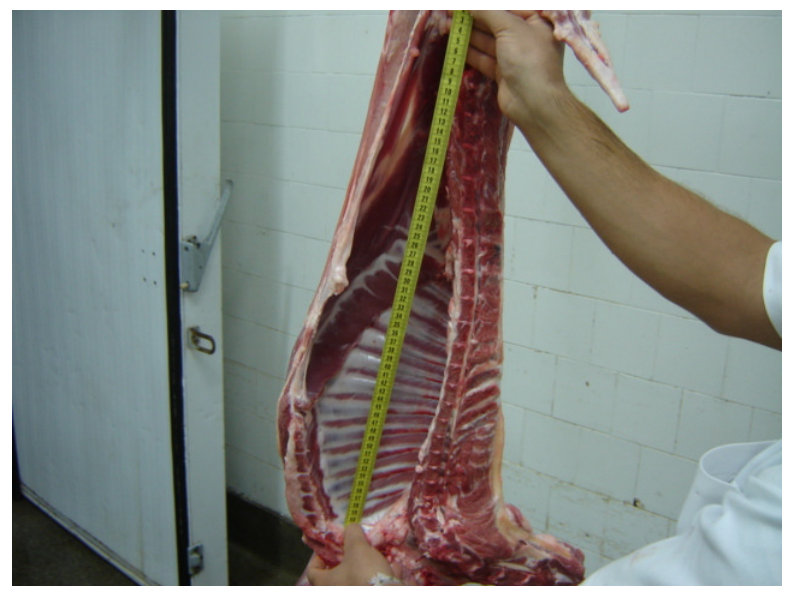

Figura 11. Determinação do índice de compacidade das meias-carcaças esquerda.

\subsection{5 Área de olho-de-lombo e espessura de gordura subcutânea}

As avaliações de área de olho-de-lombo $\left(\mathrm{AOL}, \mathrm{cm}^{2}\right)$ e a espessura de gordura subcutânea (EGS, mm) foram realizadas entre a $12^{\mathrm{a}}$ e $13^{\mathrm{a}}$ costelas, com auxílio de uma régua quadriculada específica, com escala em $0,25 \mathrm{~cm}^{2}$, pelo método de quadrante de pontos (figura 12). A referência para avaliar a EGS foi a borda central do músculo Longissimus.

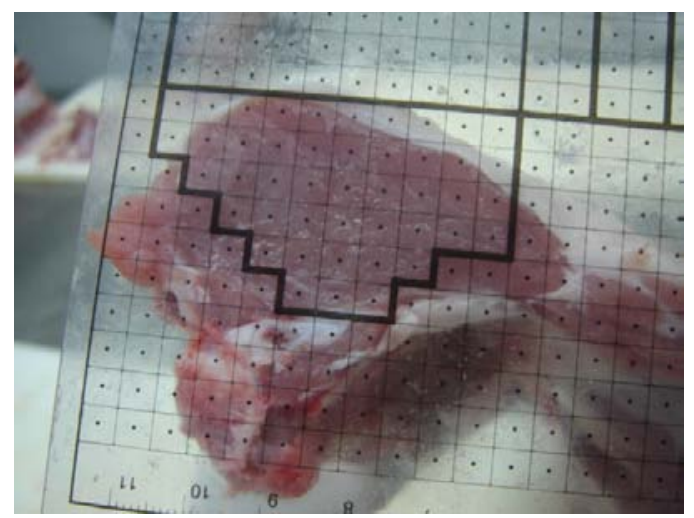

Figura 12. Mensuração da área de olho-de-lombo do músculo Longissimus, entre a $12^{\mathrm{a}}$ e $13^{\mathrm{a}}$ costelas. 


\subsubsection{Perda de água por exsudação, perdas por cocção e maciez}

Duas amostras, de 2,5 cm de espessura, do músculo Longissimus, foram coletadas por animal, embaladas a vácuo e maturadas por sete dias ou não, em câmara fria $\left(0\right.$ a $\left.2^{\circ} \mathrm{C}\right)$, com posterior congelamento, à $-15^{\circ} \mathrm{C}$, até o momento das determinações.

As amostras foram descongeladas em refrigerador doméstico à $4^{\circ} \mathrm{C}$, durante 24 horas, o suco foi coletado cuidadosamente em um béquer, com peso prédeterminado, e pesado para análise da perda de água por exsudação (PAE, \%), calculada através da fórmula:

$$
P A E=\frac{P e}{(P i+P e)} \times 100
$$

Onde: Pe: peso do exsudado (g);

Pi: peso inicial do bife $(\mathrm{g})$, anteriormente ao cozimento.

As mesmas amostras foram, posteriormente, cozidas em forno elétrico à $170^{\circ} \mathrm{C}$, até que atingissem a temperatura de $70^{\circ} \mathrm{C}$ no centro geométrico destas, monitorada por meio de termômetro, equipado com leitor digital (SILVA SOBRINHO et al., 2008). Realizou-se, então, o cálculo de perda por cocção (PPC, \%), segundo a fórmula:

$$
P P C=\frac{(P i-P f)}{P i} \times 100
$$

Onde: $\mathrm{Pi}=$ pesagem inicial do bife $(\mathrm{g})$;

$\mathrm{Pf}=$ pesagem final do bife $(\mathrm{g})$, após cozimento.

As pesagens foram realizadas em balança semi-analítica. 
$\mathrm{Na}$ sequência, as amostras foram deixadas em temperatura ambiente (25ํㅡ) e, após resfriamento, foram armazenadas em geladeira, à $4^{\circ} \mathrm{C}$, por 24 horas. Em seguida, foram retirados seis cilindros, com $12,7 \mathrm{~mm}$ de diâmetro, de cada amostra, para a análise de maciez (figura 13). A força de cisalhamento (FC, kg) de cada amostra foi considerada como a média dos valores dos cilindros.
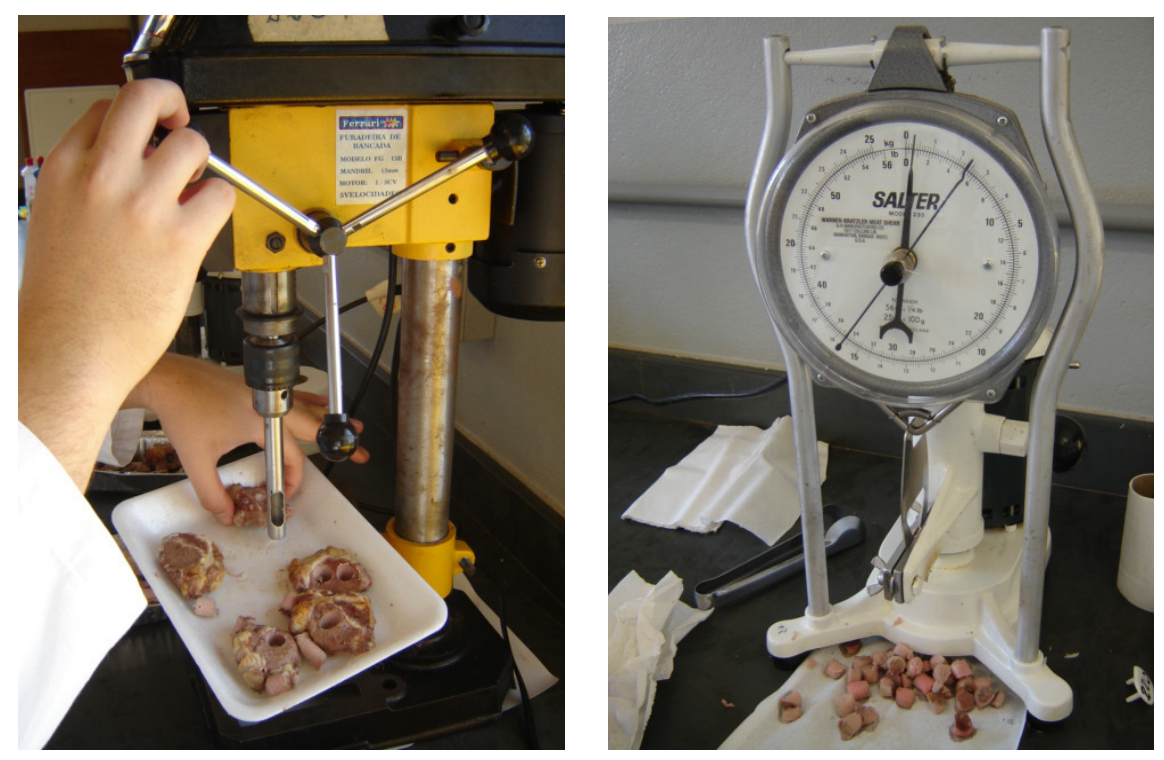

Figura 13. Retirada dos cilindros do músculo Longissimus (à esquerda) para mensuração da maciez através do aparelho Warner Bratzler Shear Force.

\subsection{Análise estatística}

O delineamento experimental utilizado foi em blocos casualizados (DBC), com o objetivo de agrupar os animais com pesos semelhantes.

O modelo matemático utilizado para as variáveis relacionadas com a digestibilidade dos nutrientes (MS, FDN, FDA, PB, EE, NDT) e amido, as características de carcaça (pesos, rendimentos, temperatura, $\mathrm{pH}$, capacidade de retenção de água, índice de compacidade, área de olho-de-lombo e espessura de 
gordura subcutânea) e os parâmetros ruminais (protozoários ciliados e pH) foi o abaixo especificado:

$$
\text { Modelo 1) } \quad y_{i j}=\mu+T_{i}+B_{j}+e_{i j}
$$

Onde: $y_{i j}=$ é o valor observado para as variáveis analisadas no animal recebendo o i-ésimo tratamento no j-ésimo bloco;

$\mu=$ média geral comum a todas as observações (constante);

$\mathrm{T}_{\mathrm{i}}=$ efeito do i-ésimo tratamento;

$B_{j}=$ efeito do j-ésimo bloco;

$\mathrm{e}_{\mathrm{ij}}=$ erro aleatório inerente a todas as observações.

Para as variáveis do desempenho animal (ganho de peso diário, ingestão de MS e conversão alimentar), dos parâmetros sanguíneos (fósforo e glicose) e das características da carne (perda de água por exsudação, perdas por cocção e força de cisalhamento), avaliadas com medidas repetidas, foi adotado o seguinte modelo:

$$
\text { Modelo 2) } \quad y_{i j k}=\mu+T_{i}+D_{j}+T D_{i j}+B_{k}+e_{i j k}
$$

Onde: $y_{\mathrm{ijk}}=$ é o valor observado para as variáveis analisadas no animal recebendo o i-ésimo tratamento, no j-ésimo dia de avaliação, submetido ao k-ésimo bloco; $\mu=$ média geral comum a todas as observações (constante);

$T_{i}=$ efeito do i-ésimo tratamento;

$D_{j}=$ efeito do j-ésimo dia de avaliação;

$T D_{i j}=$ efeito da interação entre o i-ésimo tratamento e j-ésimo dia de avaliação;

$B_{k}=$ efeito do $k$-ésimo bloco;

$e_{i \mathrm{ijk}}=$ erro aleatório inerente a todas as observações. 
Para o desempenho animal, os resultados, em função dos tratamentos, foram expressos seguindo o "modelo 1", pois estes não tiveram efeito sobre as variáveis e também não houve interação com o dia.

Os dados das variáveis, para ambos os modelos, foram submetidos à análise de variância e, quando pertinente, foram realizadas análise de regressão, em virtude dos fatores envolvidos serem quantitativos. Para o "modelo 1", os dados foram analisados pelo procedimento GLM. Já para o "modelo 2", utilizou-se o procedimento MIXED, para medidas repetidas no tempo, através da estrutura de covariância "UN" (Unestructured); somente para o fósforo sanguíneo utilizou-se a estrutura "VC" (Variance Components). Ambos os procedimento referem-se ao programa Statistical Analysis System ${ }^{\circledR}$, (SAS Institute Inc., Cary, NC).

Para o PROC MIXED, estudou-se a interação entre os efeitos principais dos tratamentos e dos dias de avaliação. Para interação significativa, procedeu-se seu desbodramento e posterior análise; nos casos de não significância, estudaram-se os efeitos principais dos fatores. O nível de significância adotado foi de $5 \%(p<0,05)$. 


\section{RESULTADOS E DISCUSSÃO}

A média geral e a variação dos dados das análises realizadas estão demonstradas na tabela 2 .

Tabela 2. Valor médio, mínimo e máximo e coeficiente de variação (CV) das análises realizadas no presente estudo.

\begin{tabular}{|c|c|c|c|c|}
\hline Variáveis & Média & Mínimo & Máximo & $\mathrm{CV}(\%)$ \\
\hline Peso vivo inicial $(\mathrm{kg})$ & 22,27 & 19,40 & 26,20 & 8,30 \\
\hline Peso vivo final $(\mathrm{kg})$ & 37,25 & 29,45 & 43,85 & 11,58 \\
\hline Ingestão de matéria seca (kg/dia) & 1,18 & 0,93 & 1,45 & 12,98 \\
\hline Ganho de peso diário (kg/dia) & 0,36 & 0,19 & 0,49 & 21,64 \\
\hline Conversão alimentar (kg ingerido/kg ganho) & 3,32 & 2,86 & 4,08 & 8,86 \\
\hline Digestibilidade da matéria seca (\%) & 80,54 & 75,47 & 86,19 & 3,93 \\
\hline Digestibilidade da fibra em detergente neutro (\%) & 60,20 & 48,76 & 72,20 & 10,92 \\
\hline Digestibilidade da fibra em detergente ácido (\%) & 58,77 & 40,67 & 76,90 & 17,36 \\
\hline Digestibilidade da proteína bruta (\%) & 81,53 & 73,38 & 88,51 & 4,61 \\
\hline Digestibilidade do extrato etéreo (\%) & 51,90 & 27,67 & 62,87 & 16,84 \\
\hline Digestibilidade dos nutrientes digestíveis totais (\%) & 83,12 & 76,52 & 87,57 & 3,59 \\
\hline Digestibilidade do Amido (\%) & 98,28 & 92,55 & 99,97 & 1,83 \\
\hline Fósforo plasmático (mg/dL) & 8,23 & 3,40 & 13,58 & 17,17 \\
\hline Glicose plasmática (mg/dL) & 93,89 & 55,73 & 170,25 & 16,32 \\
\hline \multicolumn{5}{|l|}{ Protozoários ruminais (x $10^{4}$ células/mL líquido) } \\
\hline Totais & 20,79 & 4,46 & 36,84 & 56,73 \\
\hline Entodinium sp. & 20,25 & 4,38 & 35,17 & 55,24 \\
\hline $\mathrm{pH}$ ruminal & 6,61 & 6,03 & 6,88 & 3,53 \\
\hline Peso vivo ao abate $(\mathrm{kg})$ & 39,25 & 31,50 & 46,10 & 10,14 \\
\hline Peso de carcaça quente $(\mathrm{kg})$ & 17,47 & 13,70 & 21,60 & 11,82 \\
\hline Peso de carcaça fria $(\mathrm{kg})$ & 17,36 & 13,50 & 21,30 & 11,34 \\
\hline Rendimento de carcaça quente (\%) & 44,47 & 41,20 & 48,20 & 3,85 \\
\hline Rendimento de carcaça fria (\%) & 44,20 & 42,10 & 47,50 & 3,51 \\
\hline Temperatura da carcaça $1 \mathrm{~h}$ após abate $\left({ }^{\circ} \mathrm{C}\right)$ & 30,92 & 25,80 & 33,80 & 6,40 \\
\hline Temperatura da carcaça $24 \mathrm{~h}$ após abate $\left({ }^{\circ} \mathrm{C}\right)$ & 13,99 & 11,90 & 19,00 & 12,07 \\
\hline pH da carcaça $1 \mathrm{~h}$ após abate & 6,58 & 6,12 & 6,91 & 2,92 \\
\hline $\mathrm{pH}$ da carcaça $24 \mathrm{~h}$ após abate & 5,59 & 5,50 & 5,74 & 1,16 \\
\hline Capacidade de retenção de água (\%) & 96,18 & 91,13 & 98,34 & 2,33 \\
\hline Índice de compacidade (kg/cm) & 0,29 & 0,24 & 0,35 & 9,49 \\
\hline Área de olho-de-lombo $\left(\mathrm{cm}^{2}\right)$ & 14,35 & 10,25 & 19,75 & 19,30 \\
\hline Espessura de gordura subcutânea (mm) & 2,76 & 2,00 & 4,00 & 27,82 \\
\hline Perda de água por exsudação (\%) & 1,67 & 0,25 & 3,10 & 46,81 \\
\hline Perdas por cocção (\%) & 23,89 & 14,42 & 58,19 & 27,48 \\
\hline Força de cisalhamento $(\mathrm{kg})$ & 3,04 & 2,28 & 5,52 & 22,29 \\
\hline
\end{tabular}




\subsection{Desempenho animal}

Os níveis de enzima não apresentaram efeito, frente aos animais do grupo controle, sobre os dados de desempenho avaliados, conforme tabela 3 , sendo que os valores médios para PVI, PVF, IMS, GPD e CA foram, respectivamente, 22,3 \pm $1,9 \mathrm{~kg} ; 37,3 \pm 4,3 \mathrm{~kg} ; 1,182 \pm 0,153 \mathrm{~kg} / \mathrm{dia} ; 0,356 \pm 0,077 \mathrm{~kg} / \mathrm{dia}$ e $3,3 \pm 0,3$. Os dados para o ganho de peso diário e a conversão alimentar estão de acordo com os apresentados por McAllister et al. (2000), sendo, respectivamente, 0,333 kg/dia e 3,7 $\mathrm{kg} / \mathrm{dia}$ para cordeiros Dorset com peso inicial de 21,6 $\pm 1,1 \mathrm{~kg}$.

Tabela 3. Valores médios dos dados de desempenho dos animais que receberam os diferentes níveis de enzimas.

\begin{tabular}{|c|c|c|c|c|c|c|c|c|c|}
\hline \multirow{2}{*}{ Variáveis $^{\mathrm{a}}$} & \multicolumn{4}{|c|}{ Tratamento (g enzima/kg MS) } & \multirow{2}{*}{ EPM $^{b}$} & \multicolumn{3}{|c|}{ Efeito da regressão } & \multirow{2}{*}{$\mathrm{R}^{2 \mathrm{c}}$} \\
\hline & 0 & 0,3 & 0,9 & 2,7 & & Linear & Quadrático & Desvio & \\
\hline PVI (kg) & 22,69 & 22,23 & 22,01 & 22,15 & 0,38 & 0,3793 & 0,1962 & 0,6493 & 0,90 \\
\hline PVF $(\mathrm{kg})$ & 38,31 & 36,13 & 37,28 & 37,47 & 0,90 & 0,9644 & 0,6810 & 0,3643 & 0,57 \\
\hline IMS (kg/dia) & 1,21 & 1,14 & 1,21 & 1,18 & 0,03 & 0,9106 & 0,8673 & 0,4228 & 0,42 \\
\hline GPD (kg/dia) & 0,37 & 0,33 & 0,36 & 0,37 & 0,02 & 0,7527 & 0,9620 & 0,4594 & 0,26 \\
\hline $\mathrm{CA}$ & 3,31 & 3,28 & 3,39 & 3,29 & 0,06 & 0,9401 & 0,6969 & 0,5900 & 0,23 \\
\hline
\end{tabular}

a PVI: peso vivo inicial; PVF: peso vivo final; IMS: ingestão de matéria seca; GPD: ganho de peso diário; CA: conversão alimentar (kg ingerido/kg ganho). ${ }^{b} \mathrm{EPM}$ : erro padrão da média. ${ }^{c} R^{2}$ : coeficiente de determinação.

Para demonstrar melhor os resultados apresentados acima, as figuras 14 e 15 evidenciam os dados de PVI e PVF e IMS, GPD e CA, respectivamente. 


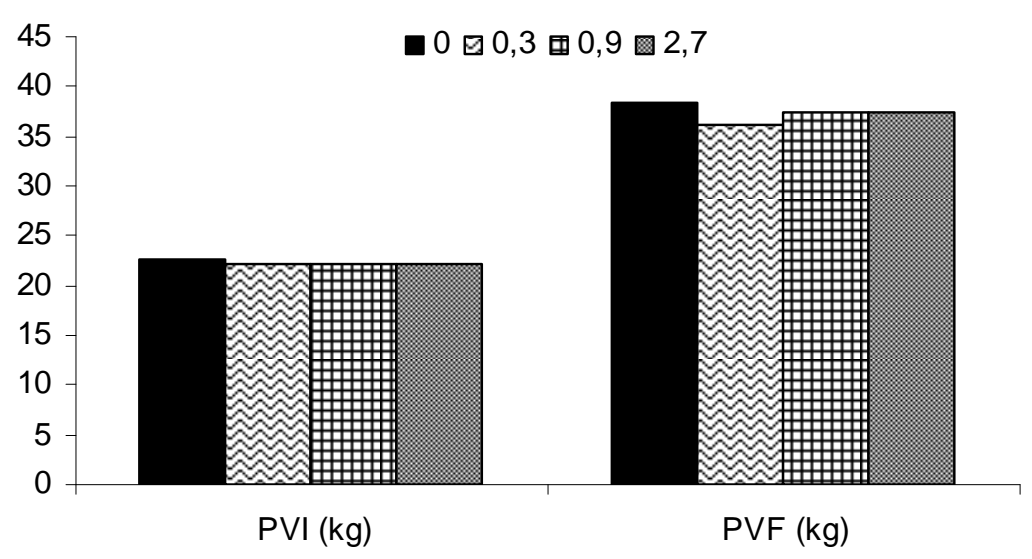

Figura 14. Valores médios do peso vivo inicial (PVI) e final (PVF) dos animais que receberam os diferentes níveis de enzima.

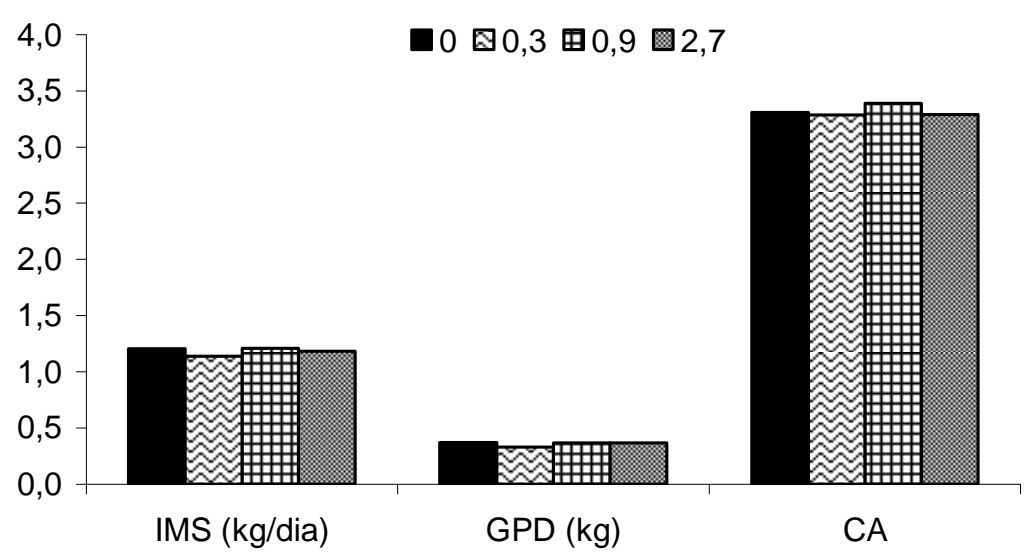

Figura 15. Valores médios da ingestão de matéria seca (IMS), ganho de peso diário (GPD) e conversão alimentar $(\mathrm{CA}=\mathrm{kg}$ ingerido $/ \mathrm{kg}$ ganho) dos animais que receberam os diferentes níveis de enzima.

Sabe-se que há muitas fontes de variação envolvidas na ausência de resposta das enzimas exógenas sobre os parâmetros estudados. Existem evidências de que, em dietas de alto grão, quando este apresenta boa digestibilidade, com no caso dos grãos de milho e soja utilizados, a adição de enzimas não surte efeito no desempenho dos animais, uma vez que a energia não se constitui o nutriente limitante (BEAUCHEMIN et al., 2003). Além disso, os ovinos parecem utilizar melhor o alimento do que os bovinos - como constatado por Yang 
et al. (2000), ao encontrarem maior digestibilidade da MS para os cordeiros recebendo a mesma composição da dieta de novilhos - o que diminui ainda mais a probabilidade de se obter resposta positiva com o uso destes tipos de produto.

Muwalla et al. (2007), avaliando a inclusão de enzimas fibrolíticas sobre a digestibilidade dos nutrientes e desempenho de cordeiros da raça Awassi, alimentados com dietas de alto concentrado $(83 \%$, contendo farelo de trigo, grãos de cevada e farelo de soja), também não verificaram diferenças significativas para as variáveis testadas. As médias de ingestão de matéria seca (IMS), ganho médio diário (GMD) e conversão alimentar (CA) foram de 1,078 kg/dia, 0,222 kg/dia e 5,4, respectivamente.

Portanto, é importante ressaltar que, talvez, o produto enzimático utilizado no presente trabalho possa ser eficaz para ovinos recebendo dietas de alto volumoso (VICINI et al. 2003) ou alto concentrado que apresente baixa digestibilidade (ROJO et al., 2005).

Os cordeiros tiveram ganho de peso crescente durante o período experimental de 42 dias, com média de 0,356 kg/dia (figura 16). Este ganho é compatível com os de animais cruzados lle de France alimentados com dietas de alto grão. Entretanto, Rojo et al. (2005) encontraram ganhos mais modestos para cordeiros Suffolk dos grupos controle, $\alpha$-amilase e glicoamilase $(0,237 ; 0,270$ e 0,257, respectivamente); porém, a dieta utilizada continha $70 \%$ de sorgo, que tem com característica a baixa digestibilidade. 


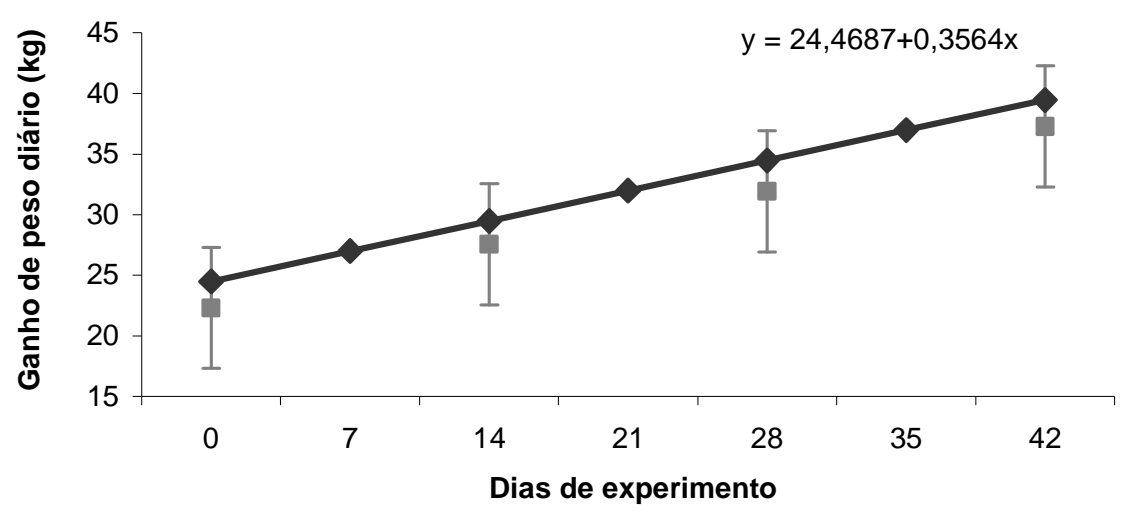

Figura 16. Regressão e equação estimadas do ganho de peso diário dos animais que receberam os diferentes níveis de enzima durante o período experimental.

Conforme tabela 1, os níveis de NDT (média de 78,07\%) e PB (média de $21,95)$ observados para todos os tratamentos estiveram acima dos exigidos por cordeiros tardios (como lle de France), com quatro meses de idade, $30 \mathrm{~kg}$ de peso vivo e ganhos de peso entre 0,300 e $0,400 \mathrm{~kg} / \mathrm{dia}$, segundo NRC (2007), não se constituindo, desta forma, um fator limitante para o desenvolvimento dos animais.

Da mesma forma que as outras variáveis de desempenho, a ingestão de matéria seca em porcentagem do peso vivo (IMS, \%PV) também não foi afetada pela adição dos níveis de enzima ao alimento. Notou-se que, à medida que os animais foram se desenvolvendo ao longo do tempo, houve uma queda linear para esta variável, ou seja, conforme se aumentou o peso corporal, os cordeiros ingeriram, proporcionalmente, menos matéria seca em relação ao peso vivo (figura 17). Como a ingestão de alimentos de boa qualidade é controlada essencialmente pela exigência energética de mantença e produção, este resultado era fisiologicamente esperado, uma vez que, com o desenvolvimento dos animais, há uma diminuição da energia necessária para produção, com consequente queda no consumo de alimentos em relação ao peso corporal. 


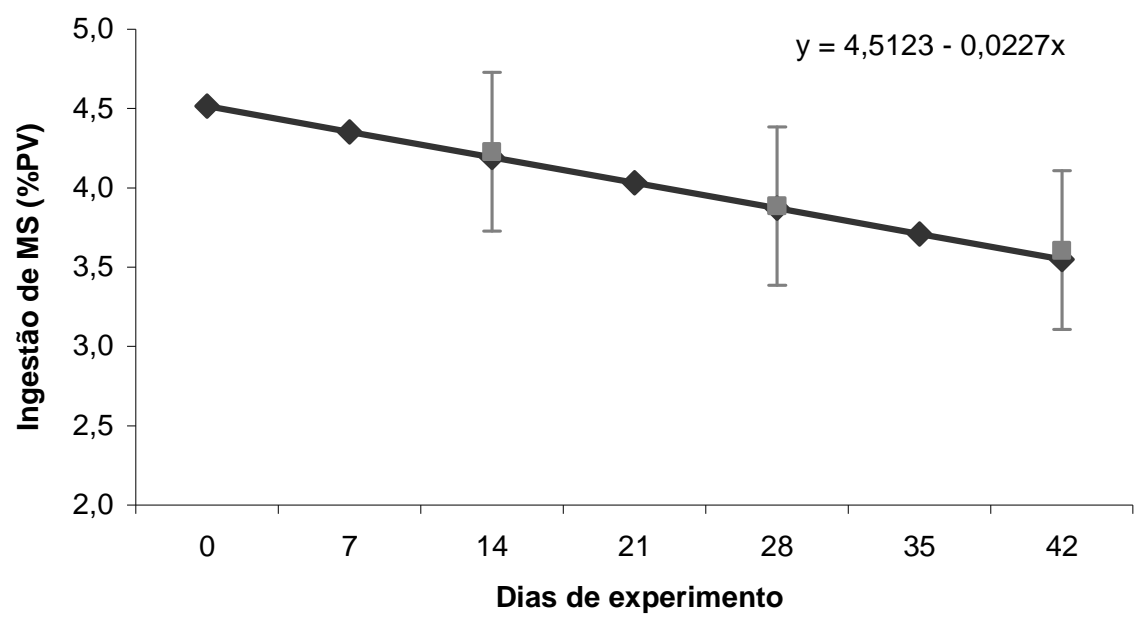

Figura 17. Regressão e equação estimadas da ingestão de matéria seca em relação ao peso vivo (\%PV) dos animais que receberam os diferentes níveis de enzima durante o período experimental.

Assim como neste trabalho, Theurer et al. (1963), utilizando uma mistura de enzimas amilolíticas, celulolíticas e proteolíticas, não encontraram alteração no ganho médio diário e conversão alimentar de cordeiros alimentados com milho ou feno. McAllister et al. (2000) verificaram que a utilização de enzimas fibrolíticas também não foi eficiente em aumentar a ingestão de alimentos ou o ganho de peso diário de cordeiros alimentados com dietas a base de cevada ou feno.

Analisando a variação numérica da média de ingestão de matéria seca dos animais por tratamento, durante os 42 dias de avaliação (figura 18), pode-se perceber que não houve grande amplitude entre os valores dentro e entre os tratamentos, sugerindo que os cordeiros suportaram bem a dieta de alto concentrado, sem sintomas de acidose subclínica, e que a adição de enzimas ao alimento não teve efeito sobre este parâmetro, diferentemente do constatado por Beauchemin et al. (1999b) em novilhas, que verificaram uma variação maior da IMS ao longo do período experimental para o grupo controle (sem enzima). 


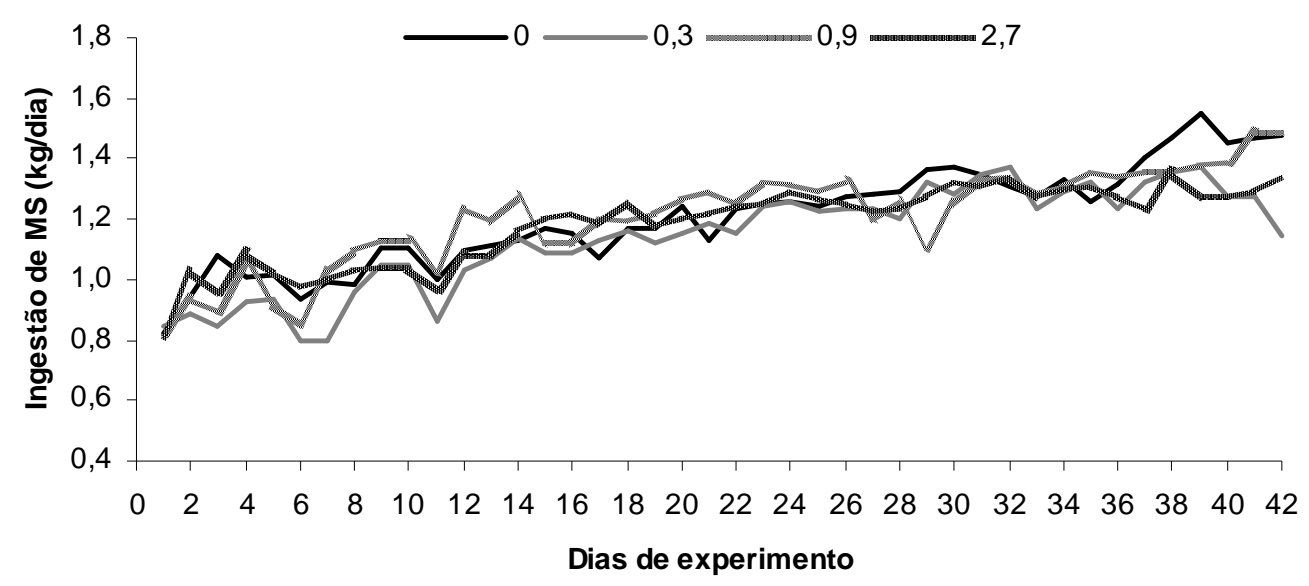

Figura 18. Variação da ingestão de matéria seca (IMS) dos animais que receberam os diferentes níveis de enzima durante o período experimental.

\subsection{Digestibilidade aparente dos nutrientes e do amido}

A média de digestibilidade da MS, FDN, FDA, PB, EE, NDT e amido foram respectivamente: 80,$55 ; 60,14 ; 58,80 ; 81,55 ; 52,02 ; 83,16$ e $98,20 \%$ (tabela 4 ). Estes valores são condizentes com os valores estimados para os alimentos utilizados na dieta (milho e soja), que apresentam alta digestibilidade. A digestibilidade quase que total do amido é comum em dietas de grãos que são ricos nesta substância e que sofrem um processamento mecânico (moagem), como neste experimento. Rojo et al. (2005) observaram média de 95,9\% para a digestibilidade do amido em dietas contendo $70 \%$ de sorgo, oferecidas para ovinos. 
Tabela 4. Valores médios da digestibilidade dos nutrientes e amido da dieta adicionada dos diferentes níveis de enzima.

\begin{tabular}{|c|c|c|c|c|c|c|c|c|c|}
\hline \multirow{2}{*}{ Digestibilidade (\%) ${ }^{\mathrm{a}}$} & \multicolumn{4}{|c|}{ Tratamento (g enzima/kg MS) } & \multirow{2}{*}{ EPM $^{b}$} & \multicolumn{3}{|c|}{ Efeito da regressão } & \multirow{2}{*}{$\mathrm{R}^{2 \mathrm{c}}$} \\
\hline & 0 & 0,3 & 0,9 & 2,7 & & Linear & Quadrático & Desvio & \\
\hline MS & 80,31 & 79,52 & 80,94 & 81,45 & 0,66 & 0,3673 & 0,9438 & 0,5923 & 0,38 \\
\hline FDN & 56,42 & 61,11 & 58,59 & 64,42 & 1,37 & $0,0853^{*}$ & 0,9175 & 0,2564 & 0,36 \\
\hline FDA & 45,70 & 62,60 & 59,53 & 67,37 & 2,13 & 0,0004 & 0,0840 & $0,0028^{\star}$ & 0,75 \\
\hline PB & 82,08 & 78,40 & 82,11 & 83,61 & 0,79 & 0,1075 & 0,6660 & 0,0709 & 0,45 \\
\hline EE & 52,13 & 51,47 & 54,83 & 49,66 & 1,82 & 0,6283 & 0,5341 & 0,7044 & 0,26 \\
\hline NDT & 83,05 & 82,19 & 83,84 & 83,54 & 0,67 & 0,8765 & 0,7686 & 0,7149 & 0,37 \\
\hline Amido & 97,34 & 98,93 & 97,81 & 98,74 & 0,40 & 0,9352 & 0,8788 & 0,2809 & 0,42 \\
\hline
\end{tabular}

${ }^{a}$ MS: matéria seca; FDN: fibra em detergente neutro; FDA: fibra em detergente ácido; PB: proteína bruta; EE: extrato etéreo; NDT: nutrientes digestíveis totais. ${ }^{b}$ EPM: erro padrão da média. ${ }^{c}$ R2: coeficiente de determinação. * Equações de regressão descritas nas figuras a seguir.

A digestibilidade da FDN apresentou uma tendência $(p=0,09)$ de efeito linear crescente, ou seja, o aumento do nível de enzimas causou uma melhora de até $11 \%$ na utilização deste nutriente pelo organismo animal (figura 19). Este resultado é condizente com vários trabalhos da literatura, que utilizaram enzimas fibrolíticas, principalmente celulase e xilanase, em dietas volumosas (Beauchemin et al., 1995; Feng et al., 1996). Portanto, no presente estudo, as enzimas fibrolíticas do complexo enzimático provavelmente atuaram sobre a parede celular do feno de Coast cross, uma vez que os outros ingredientes da dieta apresentam concentrações relativamente baixas de FDN, com consequente aumento da proporção digestível desta.

Martins et al. (2006), avaliando silagem de milho ou feno de tifton 85, na proporção de $70 \%$ da dieta, tratados ou não com produto enzimático composto por celulase e xilanase, encontraram aumento significativo na digestibilidade (de 31,49 para $39,20 \%$ na ausência ou presença do produto, respectivamente) quando a enzima foi adicionada somente ao feno. 


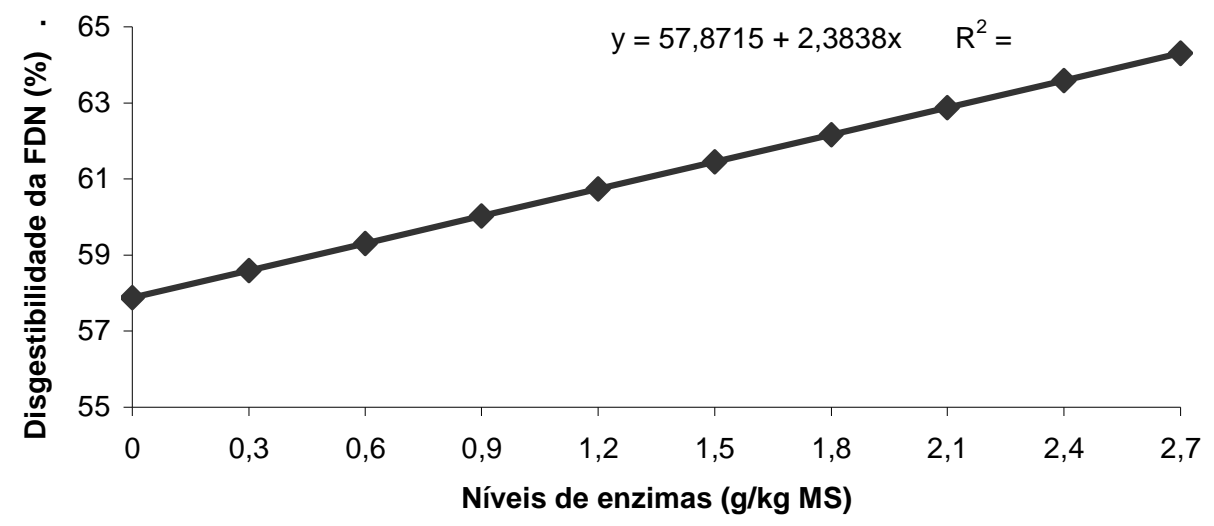

Figura 19. Regressão e equação estimadas da digestibilidade da fibra em detergente neutro (FDN) para os diferentes níveis de enzima.

Para a digestibilidade da FDA, observou-se efeito de desvio da regressão quadrática (figura 20), que não pode ser explicado pelas informações da literatura. Superdosagens podem competir com os microrganismos pelos mesmos sítios de adesão do substrato, prejudicando a eficiência geral, o que poderia explicar uma resposta quadrática, mas não de desvio, como evidenciado.

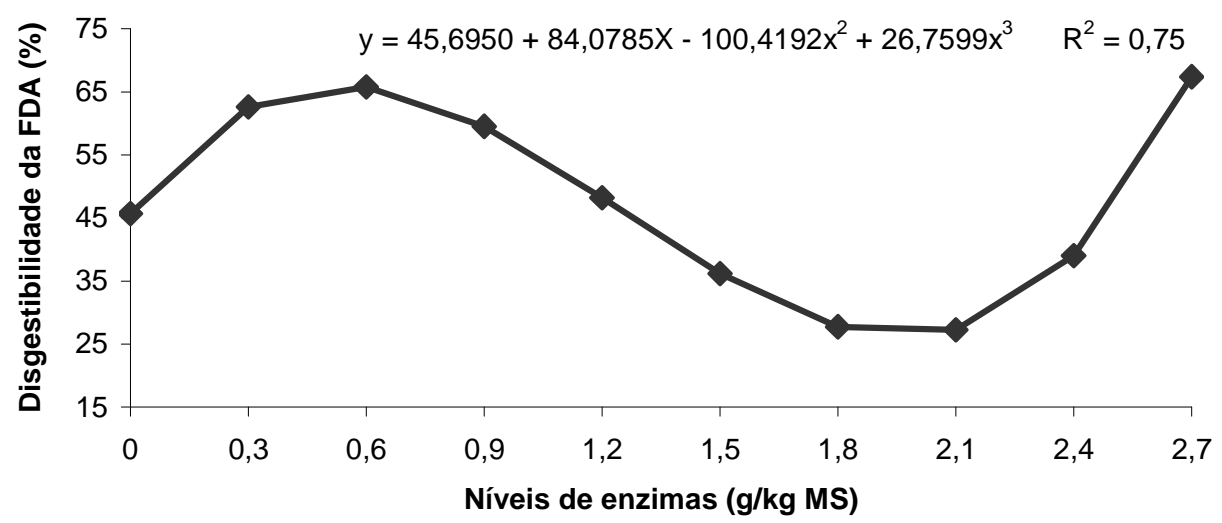

Figura 20. Regressão e equação estimadas da digestibilidade da fibra em detergente ácido (FDA) para os diferentes níveis de enzima.

Para os demais nutrientes, a adição de qualquer nível enzimático não foi eficaz em alterar a digestibilidade. 


\subsection{Parâmetros sanguíneos}

A adição do complexo enzimático não afetou as concentrações de fósforo e glicose plasmáticos; entretanto, estas foram influenciadas de forma diferente à medida que os cordeiros foram se desenvolvendo (tabela 5). As concentrações de fósforo sérico apresentaram um efeito linear crescente, sendo que as médias para os dias $0,14,28$ e 42 foram, respectivamente, 7,62; 7,91; 8,22 e 9,24 mg/dL, com valor mínimo de 3,40, e máximo de 13,58 (figura 21).

A ineficácia do produto em elevar os níveis séricos de fósforo talvez possa estar associada à baixa atividade enzimática da fitase presente, que não foi suficiente em promover maior disponibilidade deste mineral, o que, teoricamente, elevaria a sua concentração sanguínea. 
Tabela 5. Valores médios das concentrações plasmáticas de fósforo $(\mathrm{P})$ e glicose (Gli) dos animais que receberam os diferentes níveis de enzima.

\begin{tabular}{|c|c|c|c|c|c|c|c|c|c|c|c|c|c|c|c|c|c|c|c|c|}
\hline \multirow{2}{*}{ Variável } & \multicolumn{4}{|c|}{ Dia 0} & \multicolumn{4}{|c|}{ Dia 14} & \multicolumn{4}{|c|}{ Dia 28} & \multicolumn{4}{|c|}{ Dia 42} & \multirow{2}{*}{$\mathrm{EPM}^{1}$} & \multicolumn{3}{|c|}{ Efeito $^{2}$} \\
\hline & 0 & 0,3 & 0,9 & 2,7 & 0 & 0,3 & 0,9 & 2,7 & 0 & 0,3 & 0,9 & 2,7 & 0 & 0,3 & 0,9 & 2,7 & & ENZ & DIA & $E N Z \times$ DIA \\
\hline $\mathrm{P}(\mathrm{mg} / \mathrm{dL})$ & 7,8 & 6,6 & 8,4 & 7,6 & 7,7 & 8,0 & 8,3 & 7,6 & 8,2 & 9,0 & 7,9 & 7,7 & 9,3 & 9,7 & 9,5 & 8,5 & 0,1 & 0,3958 & $0,0006^{*}$ & 0,4366 \\
\hline Gli (mg/dL) & 81,5 & 86,5 & 90,4 & 87,2 & 99,2 & 89,9 & 98,1 & 91,3 & 94,7 & 90,6 & 102,6 & 94,2 & 114,7 & 84,6 & 106,7 & 93,1 & 1,6 & 0,0875 & $0,0001^{*}$ & $0,0114^{\star}$ \\
\hline
\end{tabular}

'EPM: erro padrão da média. ${ }^{2}$ ENZ: efeito da enzima; DIA: efeito do dia; ENZ x DIA; efeito da interação enzima vs. dia; ${ }^{*}$ Equações de regressão descritas nas figuras a seguir. 
Contudo, trabalhos que avaliaram o nível plasmático de fósforo em ruminantes recebendo dietas tratadas com enzimas exógenas são escassos na literatura, necessitando de mais pesquisas nesta área.

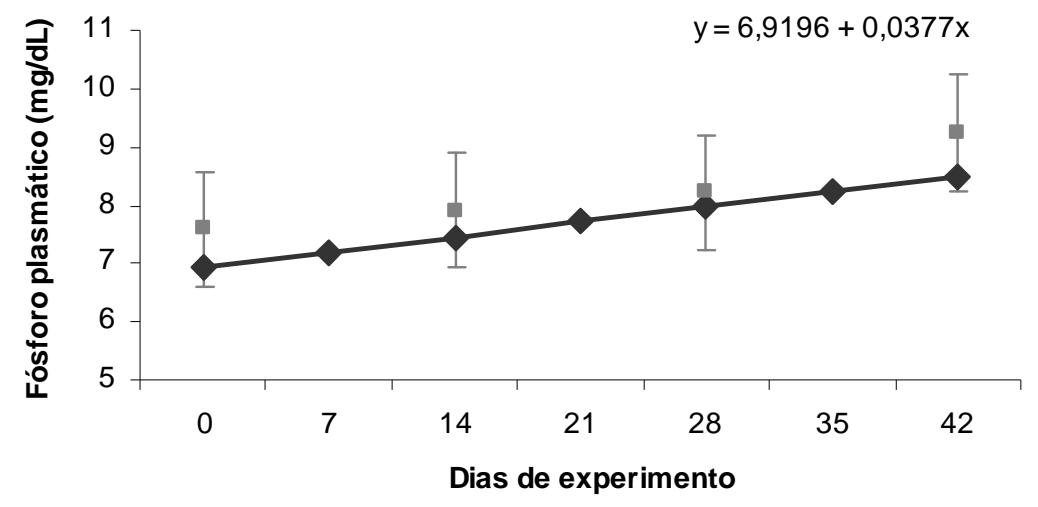

Figura 21. Regressão e equação estimadas das concentrações de fósforo plasmático dos animais durante o período experimental.

Para as concentrações de glicose sérica, houve interação entre os fatores enzima vs. dia (figura 22). Observa-se que as concentrações de glicose plasmática dos cordeiros que não receberam enzimas (grupo controle) tiveram uma maior variação ao longo do período experimental. Contudo, os animais suplementados com enzimas (tratamentos 0,3; 0,9 e 2,7) apresentaram concentrações iniciais de glicose mais altas que do grupo controle, sendo que este fato contribuiu para a maior amplitude dos dados para os animais sem suplementação; mas evidencia-se que as concentrações finais dos cordeiros suplementados foram mais baixas. Portanto, existiu algum mecanismo que possibilitou que estas concentrações permanecessem mais constantes durante o desenvolvimento dos animais, porém, não foi possível encontrar, na literatura, uma explicação plausível para tal resultado.

As médias para os dias $0,14,28$ e 42, iguais a 86,$41 ; 94,60,95,55,99,79$ $\mathrm{mg} / \mathrm{dL}$, respectivamente, com amplitude entre 55,73 e 170,25. Estes valores foram 
superiores aos encontrados por Ramin et al. (2005), com média observada, em ovelhas não gestantes, de 46,89 mg/dL, e amplitude de 24,7 a 73,0 mg/dL. Ainda, Radotits et al. (2000, citado por Ramin et al., 2005) relataram valores normais entre 35 e $45 \mathrm{mg} / \mathrm{dL}$.

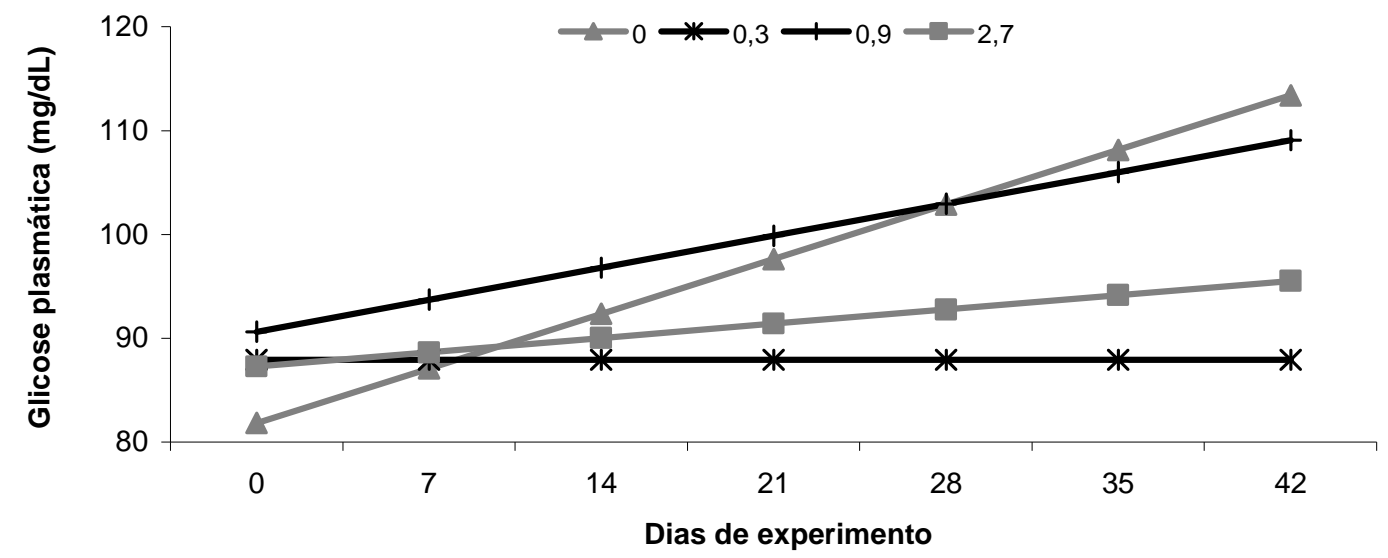

Figura 22. Regressão estimada das concentrações de glicose plasmática dos animais durante os dias de experimento, para os diferentes níveis de enzima.

$\mathrm{y}_{0}=81,8070+0,7522 \mathrm{x}$ $\mathrm{y}_{0,3}=87,9100$;

$$
\begin{aligned}
& y_{0,9}=90,5949+0,4400 x ; \\
& y_{2,7}=87,2448+0,1967 x .
\end{aligned}
$$

Pode-se sugerir que esta divergência de valores, quando comparados aos dados da literatura, talvez tenha ocorrido pelo tipo de dieta utilizada, caracterizada pela alta proporção de grãos ricos em amido e de alta digestibilidade, como o milho, com $72 \%$ de amido (HUNTINGTON, 1997). Este fato pode ter elevado os valores de glicose plasmática, embora esta informação não tenha sido encontrada na literatura.

Alguns autores verificaram efeito da adição de enzimas sobre a concentração de glicose plasmática. Tricarico et al. (2005), avaliando os efeitos da a-amilase, nos níveis $0 ; 240 ; 480$ e 720 DU/kg de MS, para vacas de leite, encontraram aumento linear da concentração de glicose. No entanto, o menor nível utilizado foi superior ao maior nível do presente estudo. 


\subsection{Parâmetros ruminais}

A identificação e contagem dos protozoários ciliados do rúmen de ovinos que receberam diferentes níveis de enzimas adicionadas ao alimento estão demonstradas na tabela 6. Consideraram-se apenas os efeitos linear e quadrático, com o objetivo de facilitar a interpretação biológica da variável envolvida.

Foram observados protozoários dos gêneros Entodinium, Diplodinium, Isotricha, Dasytricha e Epidinium. Porém, o gênero Entodinium representou mais de 95\% do total de protozoários do rúmen para todos os níveis enzimáticos avaliados. Dietas concentradas diminuem o número de protozoários ciliados, sendo os desse gênero os que melhor sobrevivem a este meio (TOWNE et al., 1990). Mendoza et al. (1993) citaram que a presença de protozoários ciliados reduz a taxa e extensão da digestão ruminal do amido, mas este fato não foi verificado no presente estudo, com pode ser confirmado nos dados de digestibilidade do amido, que não foram diferentes para os diversos níveis de enzima utilizados.

Tabela 6. Valores médios, erro padrão da média (EPM), probabilidades dos efeitos da regressão e coeficiente de determinação $\left(R^{2}\right)$ da população de protozoários ciliados do rúmen dos animais que receberam os diferentes níveis de enzima.

\begin{tabular}{|c|c|c|c|c|c|c|c|c|}
\hline \multirow{2}{*}{$\begin{array}{l}\text { Protozoários } \\
\left.\text { (x } 10^{4} \text { células } / \mathrm{mL}\right)\end{array}$} & \multicolumn{4}{|c|}{ Tratamento ( $\mathrm{g}$ de enzima/Kg de MS) } & \multirow{2}{*}{ EPM } & \multicolumn{2}{|c|}{ Efeitos da regressão } & \multirow{2}{*}{$\mathrm{R}^{2}$} \\
\hline & 0,0 & 0,3 & 0,9 & 2,7 & & Linear & Quadrática & \\
\hline Entodinium $^{1}$ & 4,64 & 15,75 & 24,49 & 34,21 & 2,39 & 0,0001 & 0,0001 & 0,97 \\
\hline Diplodinium $^{2}$ & 0 & 0 & 0 & 0,62 & 0,06 & 0,0001 & 0,0002 & 0,95 \\
\hline Isotricha $^{3}$ & 0,05 & 0 & 0,15 & 0,31 & 0,03 & 0,0001 & 0,9594 & 0,83 \\
\hline Dasytricha $^{4}$ & 0 & 0 & 0 & 0,32 & 0,03 & 0,0001 & 0,0004 & 0,93 \\
\hline Epidinium $^{5}$ & 0 & 0 & 0,23 & 0,40 & 0,04 & 0,0001 & 0,0014 & 0,92 \\
\hline Total $^{6}$ & 4,698 & 15,752 & 24,874 & 35,852 & 2,515 & 0,0001 & 0,0001 & 0,98 \\
\hline $\begin{array}{l}y_{\text {Diplodinium }}=0,009 \\
y_{\text {lsotricha }}=0,0193\end{array}$ & $\begin{array}{l}7,2828 \\
1170 x \\
078 x\end{array}$ & 6,2577 & & $\begin{array}{l}{ }^{5} \mathrm{y}_{\text {Das }} \\
{ }^{6} \mathrm{y}_{\text {Epic }} \\
{ }^{6} \mathrm{y}_{\text {Tota }}\end{array}$ & 00 & $\begin{array}{l}0-0,0 \\
82+0 \\
27,549\end{array}$ & $\begin{array}{l}4 x+0,06 \\
44 x-0,05 \\
-6,1304 x\end{array}$ & \\
\hline
\end{tabular}

Para todos os gêneros encontrados, com exceção do gênero Isotricha, observou-se um efeito quadrático (figura 23). Os níveis de enzimas que 
proporcionaram maior aumento do número de protozoários totais e de Entodinium foram, respectivamente, 2,25 e 2,18 g/Kg MS. A queda observada após estes níveis pode ser devida a superdosagens, que competem com os microrganismos pelos mesmos sítios de adesão ao substrato, ou então liberam fatores antinutricionais tóxicos.

Os resultados sugerem que a adição do produto enzimático foi eficiente em aumentar a disponibilidade de frações específicas dos alimentos para ataque, alimentação e multiplicação dos microrganismos ruminais.



Figura 23. Regressões e equações estimadas do número de protozoários ruminais total e do gênero Entodinium para os diferentes níveis de enzima.

Rojo et al. (2005), ao adicionarem glicoamilase de Aspergillus niger nos níveis 0, 1,45 e 2,90 $\mathrm{g} / \mathrm{kg}$ de MS em dietas a base de sorgo oferecidas à ovinos Suffolk, também notaram que o número de protozoários apresentou efeito quadrático (16, 35 e $27 \times 10^{4}$ células $/ \mathrm{mL}$, respectivamente). Entretanto, os autores ressaltaram que as condições ruminais (pressão osmótica, $\mathrm{pH}$ e taxa de diluição) que estimularam o crescimento da população de protozoários em dietas de alto grão não puderam ser identificadas. Porém, quando os mesmos autores trabalharam com a-amilase de 
Bacillus licheniformis nas mesmas condições, observou-se que o número de protozoários declinou linearmente $\left(49,37,3\right.$ e $25 \times 10^{4}$ células $/ \mathrm{mL}$, respectivamente).

Para o pH ruminal mensurado no momento do abate, também não houve efeito da adição de enzima sobre o alimento, para qualquer nível avaliado, com média igual a 6,61 (figura 24). Este valor está acima do mencionado pela literatura, para ovinos recebendo dieta de alto concentrado (ROJO et al., 2005), mas é semelhante às médias encontradas para dietas de alto volumoso, como 6,53 (JUDKINS e STOBART, 1988) e 6,64 (HADDAD, 2000). Portanto, a fermentação ruminal possivelmente não foi afetada pela dieta de alto concentrado oferecida aos ovinos durante o período experimental.

É interessante ressaltar, porém, que o valor elevado de $\mathrm{pH}$ ruminal encontrado no presente estudo, para dietas com $87 \%$ de concentrado, pode ter sido influenciado pela coleta do líquido somente no momento do abate, uma vez que os cordeiros passaram por jejum de 12 horas, enquanto que os autores dos demais trabalhos citados realizaram a coleta ao longo do dia, em animais fistulados.

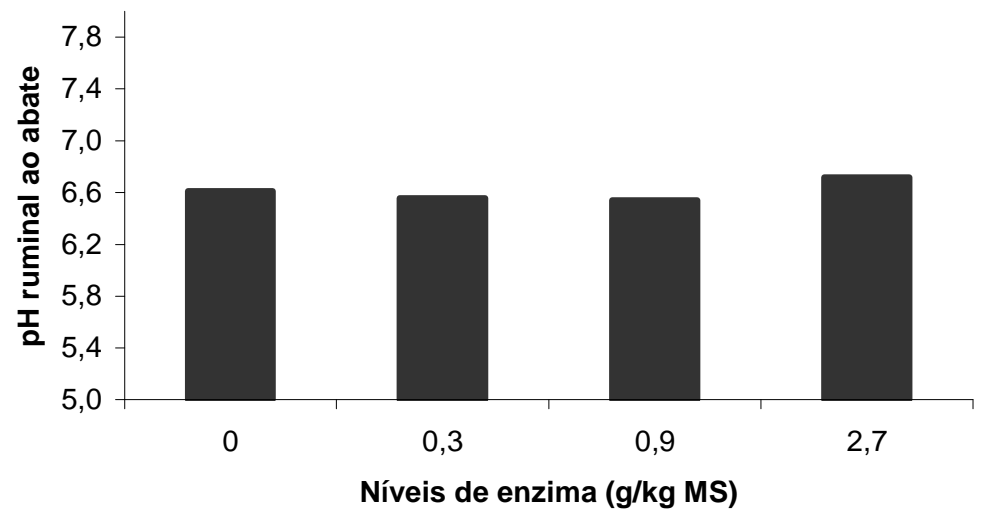

Figura 24. $\mathrm{pH}$ ruminal, mensurado ao abate, dos animais que receberam os diferentes níveis de enzima. 


\subsection{Características da carcaça e da carne}

As médias das características de carcaça analisadas estão apresentadas na tabela 7. Os rendimentos de carcaça quente e fria apresentaram uma queda à medida que se aumentou a concentração de enzima, até os níveis de 1,61 e 1,55 g de enzima/kg de MS, respectivamente, sendo que, após estes valores, as carcaças apresentaram maiores rendimentos, mas não ultrapassaram os das carcaças dos animais que não receberam enzima (figura 25). McAllister et al. (2000), avaliando produto enzimático adicionado em dieta concentrada oferecida a cordeiros, mensuraram rendimento de carcaça superior (média de 52,1\% vs. $44,5 \%$ ) aos encontrados no presente estudo, porém, a média do peso vivo ao abate foi de $52 \mathrm{~kg}$ (superioridade de $13 \mathrm{~kg}$ ).

Sabe-se que o peso vivo ao abate apresenta correlação positiva com o rendimento de carcaça, o que denota esta diferença encontrada. Em concordância a esta afirmação, Bueno et al. (2000) abateram cordeiros Suffolk com 90, 130 e 170 dias de idade e obtiveram valores para rendimentos de carcaça quente e fria iguais a, respectivamente, 44,9; 45,6 e 48,2\%, e 41,8; 43,0 e 45,9\%. O peso vivo ao abate dos animais com 130 e 170 dias de idade variaram de 32,7 a 40,9 kg, similar ao encontrado no presente estudo, sendo que a adição das enzimas não foi eficaz em melhorar esta variável, assim como para os pesos de carcaça quente e fria. 
Tabela 7. Valores médios das características da carcaça dos animais que receberam os diferentes níveis de enzima.

\begin{tabular}{|c|c|c|c|c|c|c|c|c|c|}
\hline \multirow{2}{*}{ Variáveis $^{a}$} & \multicolumn{4}{|c|}{ Tratamento ( $\mathrm{g}$ enzima/kg MS) } & \multirow{2}{*}{$\mathrm{EPM}^{\mathrm{b}}$} & \multicolumn{3}{|c|}{ Efeito da regressão } & \multirow{2}{*}{$\mathrm{R}^{2 \mathrm{c}}$} \\
\hline & 0 & 0,3 & 0,9 & 2,7 & & Linear & Quadrático & Desvio & \\
\hline \multicolumn{10}{|l|}{ Pesos (kg) } \\
\hline Vivo ao abate & 39,38 & 38,19 & 40,86 & 38,87 & 0,85 & 0,9746 & 0,4916 & 0,3594 & 0,56 \\
\hline Carcaça quente & 18,22 & 16,80 & 17,82 & 17,23 & 0,44 & 0,6658 & 0,7222 & 0,2353 & 0,55 \\
\hline Carcaça fria & 18,12 & 16,80 & 17,66 & 17,03 & 0,42 & 0,5634 & 0,7179 & 0,2845 & 0,51 \\
\hline \multicolumn{10}{|l|}{ Rendimento (\%) } \\
\hline Carcaça quente & 46,2 & 44,0 & 43,6 & 44,3 & 0,4 & 0,2497 & $0,0133^{*}$ & 0,2144 & 0,56 \\
\hline Carcaça fria & 45,9 & 44,0 & 43,2 & 43,8 & 0,3 & 0,0644 & $0,0054^{*}$ & 0,3193 & 0,61 \\
\hline $\mathrm{AOL}\left(\mathrm{cm}^{2}\right)$ & 16,65 & 13,96 & 13,70 & 13,38 & 0,59 & 0,1828 & 0,2011 & 0,3997 & 0,35 \\
\hline EGS (mm) & 3,00 & 2,60 & 2,60 & 2,83 & 0,17 & 0,9908 & 0,3203 & 0,9928 & 0,37 \\
\hline IC (kg/cm) & 0,29 & 0,30 & 0,30 & 0,28 & 0,01 & 0,4664 & 0,6223 & 0,6897 & 0,53 \\
\hline $\mathrm{pH} 1 \mathrm{~h}$ & 6,58 & 6,62 & 6,66 & 6,46 & 0,04 & 0,1705 & 0,4446 & 0,9065 & 0,28 \\
\hline $\mathrm{pH} 24 \mathrm{~h}$ & 5,62 & 5,59 & 5,60 & 5,56 & 0,01 & 0,1463 & 0,7512 & 0,5322 & 0,45 \\
\hline Temperatura $1 \mathrm{~h}\left({ }^{\circ} \mathrm{C}\right)$ & 31,3 & 31,3 & 31,2 & 30,0 & 0,4 & 0,2772 & 0,6279 & 0,9395 & 0,31 \\
\hline Temperatura $24 \mathrm{~h}\left({ }^{\circ} \mathrm{C}\right)$ & 13,0 & 13,5 & 15,4 & 14,1 & 0,4 & 0,3551 & $0,0330^{*}$ & 0,4406 & 0,50 \\
\hline CRA (\%) & 96,52 & 95,23 & 97,65 & 95,86 & 0,49 & 0,6001 & 0,1740 & $0,0361^{*}$ & 0,60 \\
\hline
\end{tabular}

aOL: área de olho-de-lombo; EGS: espessura de gordura subcutânea; IC: índice de compacidade; $\mathrm{pH} 1 \mathrm{~h}$ e $24 \mathrm{~h}=\mathrm{pH}$ da carcaça mensurado 1 e 24 horas após abate; Temperatura $1 \mathrm{~h}$ e $24 \mathrm{~h}$ : temperatura da carcaça mensurada 1 e 24 horas após abate; CRA: capacidade de retenção de água. ${ }^{b}$ EPM: erro padrão da média. ${ }^{c} R^{2}$ : coeficiente de determinação. * Equações de regressão descritas nas figuras a seguir.

Como o rendimento de carcaça é obtido dividindo-se o peso vivo animal ao abate pelo peso do corpo vazio, descontando-se a cabeça, patas, pele, lã e vísceras, e estes dados não sofreram influência dos níveis enzimáticos avaliados, supõe-se que, de alguma forma, a suplementação enzimática até o nível de 1,61 $\mathrm{g} / \mathrm{kg}$ de MS proporcionou melhora nos parâmetros de fermentação ruminal - mas não na utilização do alimento, como evidenciado nos dados de digestibilidade - que causaram maior aporte de nutrientes para o organismo, mas estes foram depositados em não componentes da carcaça. Considerando que o peso vivo ao abate e de carcaça não foram alterados, com a adição de enzima ao alimento, não 
há explicação para o fato dos níveis acima de 1,61 g de enzima/kg de MS terem causado elevação do rendimento de carcaça.

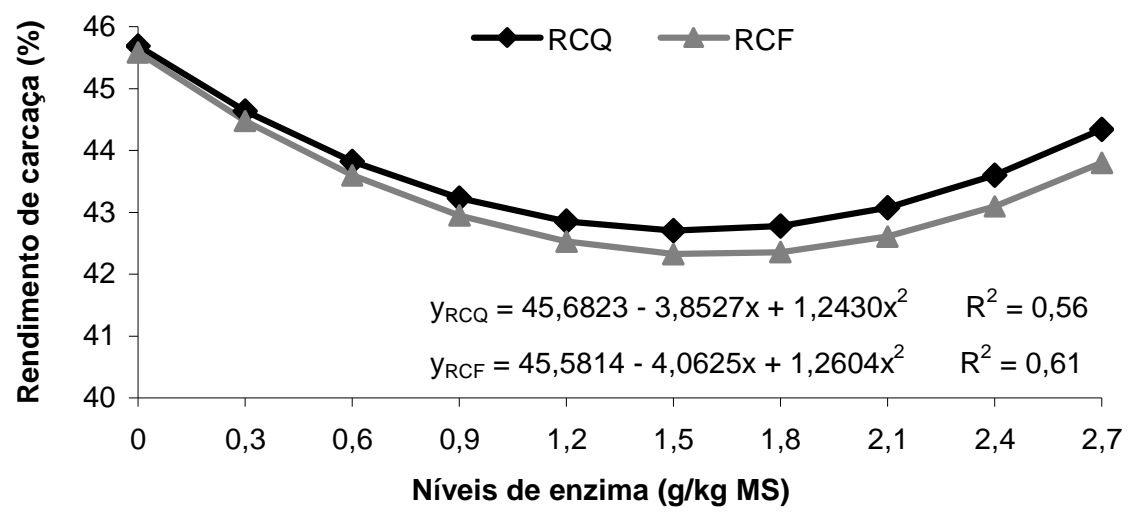

Figura 25. Regressões e equações estimadas dos rendimentos de carcaça quente (RCQ) e fria (RCF) dos animais que receberam os diferentes níveis de enzima.

O complexo enzimático avaliado não influenciou os valores de pH 1 e 24 horas após abate, temperatura 1 hora após abate, AOL, EGS e IC das carcaças.

Os valores de AOL foram semelhantes aos determinados por McAllister et al. (2000), com média de 15,7 cm². Tricarico et al. (2007), avaliando diferentes níveis de a-amilase (0, 580 e 1160 DU/kg de MS) para bovinos em terminação, encontraram distribuição quadrática dos dados para a área de olho-de-lombo, e atribuíram este efeito à melhora do ganho de peso diário dos animais suplementados com enzima, o que não pode ser comprovado no presente estudo.

Bueno et al. (2000), avaliando as características de carcaça de cordeiros Suffolk alimentados com, aproximadamente, $80 \%$ de concentrado (3,5\% do peso vivo) e abatidos com 170 dias de idade, relataram valores semelhantes aos do presente estudo para a AOL $\left(14,8 \mathrm{~cm}^{2}\right)$, EGS $(2,9 \mathrm{~mm})$ e IC $(0,31 \mathrm{~kg} / \mathrm{cm})$.

Os valores de pH 1 e 24 horas após o abate também foram similares aos relatados por Bueno et al. (2000), sendo 6,57 e 5,85, respectivamente. Lemos Neto et al. (1998, citado por Bueno et al., 2000) destaca que a queda do pH das carcaças 
para valores abaixo de 6,0, que caracteriza o processo normal de transformação dos músculos em carne, é necessária para tornar o produto adequado ao paladar humano.

A temperatura da carcaça 24 horas após o abate dos animais apresentou um comportamento quadrático, com aumento até o nível de 1,55 g de enzima/kg de MS e posterior diminuição (figura 26). Porém, a variação mínima dos valores não traz consequencias para a qualidade final da carne. Não há explicação para o fato da temperatura da carcaça 24 após abate ter sido influenciada pela adição da enzima, uma vez que, teoricamente, estes fatores não possuem, a princípio, uma relação de causa e efeito. Além disso, trabalhos que relacionam a adição de enzimas com esta variável não foram encontrados na literatura.

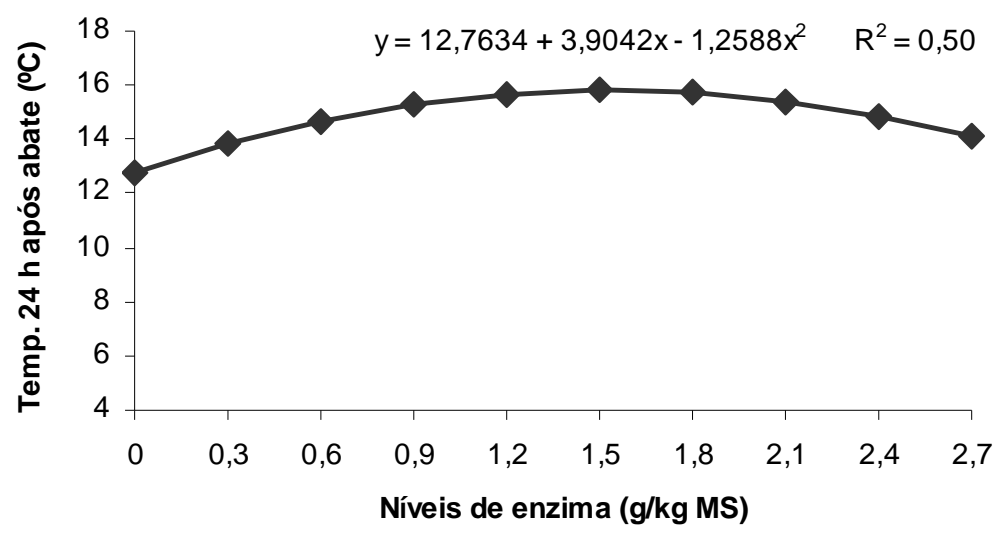

Figura 26. Regressão e equação estimadas da temperatura da carcaça, 24 horas após abate, dos animais que receberam os diferentes níveis de enzima.

Para a capacidade de retenção de água (CRA), observou-se que esta apresentou desvio da regressão quadrática (figura 27). Uma maior CRA determina melhor qualidade final da carne disponível para consumo. Para a maior parte das variáveis biológicas, resultados deste tipo são de difícil interpretação. Como o número de animais em estudo foi diminuto, e considerando que este dado também é 
escasso na literatura, fica evidente a necessidade de mais estudos para determinar, com segurança, a influência da adição de enzimas na CRA da carne de ovinos.

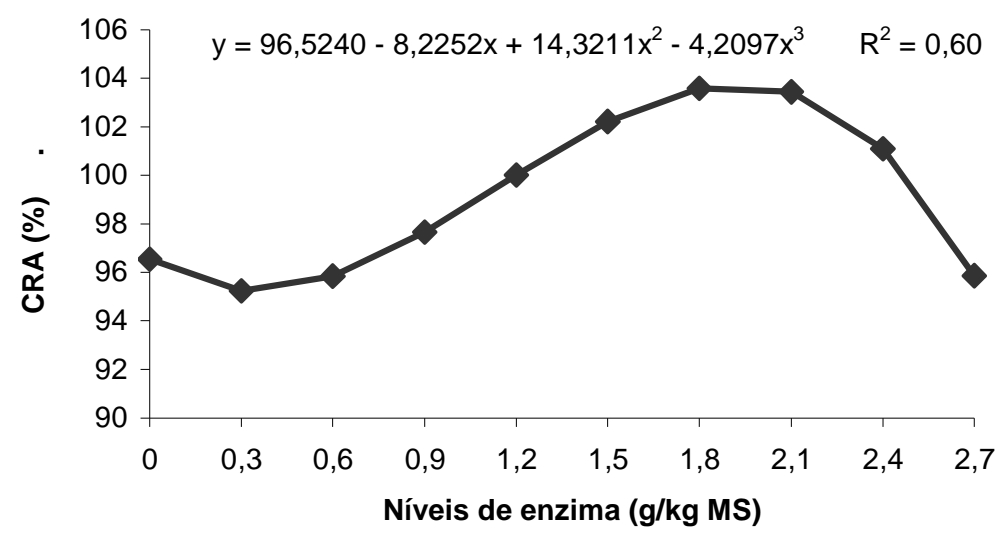

Figura 27. Regressão e equação estimadas da capacidade de retenção de água (CRA) da carne dos animais que receberam os diferentes níveis de enzima.

Pelos dados e discussões apresentados, fica evidente a falta de informação na literatura acerca de algumas características de carcaça avaliadas em cordeiros suplementados com produtos enzimáticos, denotando a importância de mais pesquisas na área.

As características da carne dos cordeiros que receberam os diferentes níveis de enzima estão demonstradas na tabela 8. A perda de água por exsudação apresentou efeito quadrático, com maior valor para a adição de 1,03 g de enzima $/ \mathrm{kg}$ de MS; porém, a variação foi pequena, de 0,25 a 3,10\%, não comprometendo, desta forma, a qualidade final da carne (figura 28). 
Tabela 8. Valores médios da perda de água por exsudação (PAE), perdas por cocção (PPC) e força de cisalhamento (FC) da carne, maturada por 7 dias ou não, dos animais que receberam os diferentes níveis de enzima.

\begin{tabular}{|c|c|c|c|c|c|c|c|c|c|c|c|c|}
\hline \multirow{2}{*}{ Variáveis } & \multicolumn{4}{|c|}{ Dia 0} & \multicolumn{4}{|c|}{ Dia 7} & \multirow{2}{*}{ EPM $^{1}$} & \multicolumn{3}{|c|}{ Efeito $^{2}$} \\
\hline & 0 & 0,3 & 0,9 & 2,7 & 0 & 0,3 & 0,9 & 2,7 & & Enz & Dia & Enz $x$ Dia \\
\hline PAE (\%) & 5,04 & 3,53 & 3,63 & 1,68 & 4,56 & 4,44 & 4,44 & 2,23 & 0,29 & $0,0117^{\star}$ & 0,2160 & 0,4044 \\
\hline PPC (\%) & 22,59 & 20,95 & 21,36 & 20,35 & 25,49 & 24,93 & 24,20 & 25,69 & 0,59 & 0,8514 & $0,0034^{*}$ & 0,8283 \\
\hline $\mathrm{FC}(\mathrm{kg})$ & 3,17 & 3,65 & 3,31 & 3,54 & 2,55 & 2,80 & 2,47 & 2,71 & 0,10 & 0,4009 & $0,0002^{*}$ & 0,9381 \\
\hline
\end{tabular}

EPM: erro padrão da média. ${ }^{2}$ ENZ: efeito da enzima; DIA: efeito do dia; ENZ x DIA; efeito da interação enzima $v s$. dia; ${ }^{*}$ Equações de regressão descritas nas figuras a seguir. 


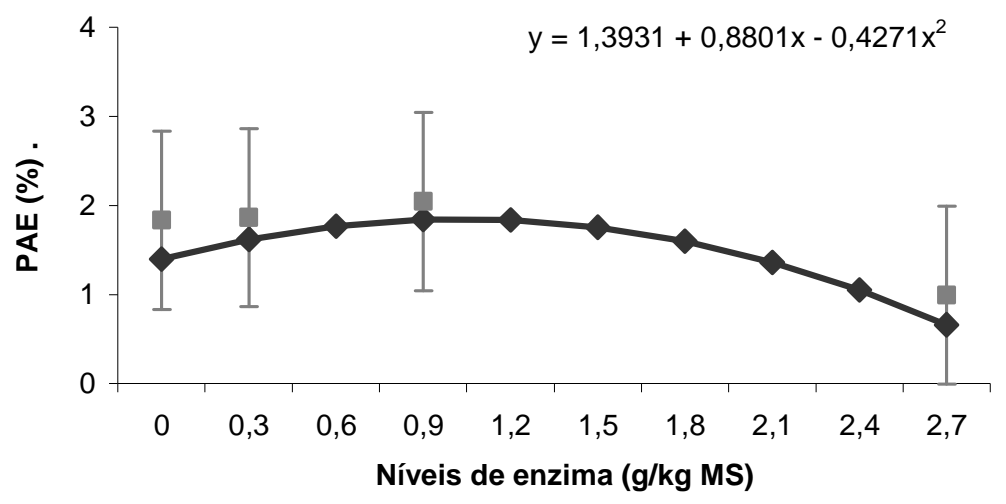

Figura 28. Regressão e equação estimadas da perda de água por exsudação (PAE) da carne dos animais que receberam os diferentes níveis de enzima.

As perdas por cocção (PPC) e a força de cisalhamento (FC) que determina a maciez da carne não foram influenciadas pela adição da enzima. Porém, a maturação apresentou um efeito linear sobre estas características. Para a primeira, observou-se que a maturação da carne por até sete dias propiciou maiores perdas por cocção em comparação à carne não maturada (figura 29). Este resultado era esperado uma vez que, com o processo de maturação, as enzimas presentes no tecido muscular continuam ativas, dando continuidade aos processos de degradação das fibras.

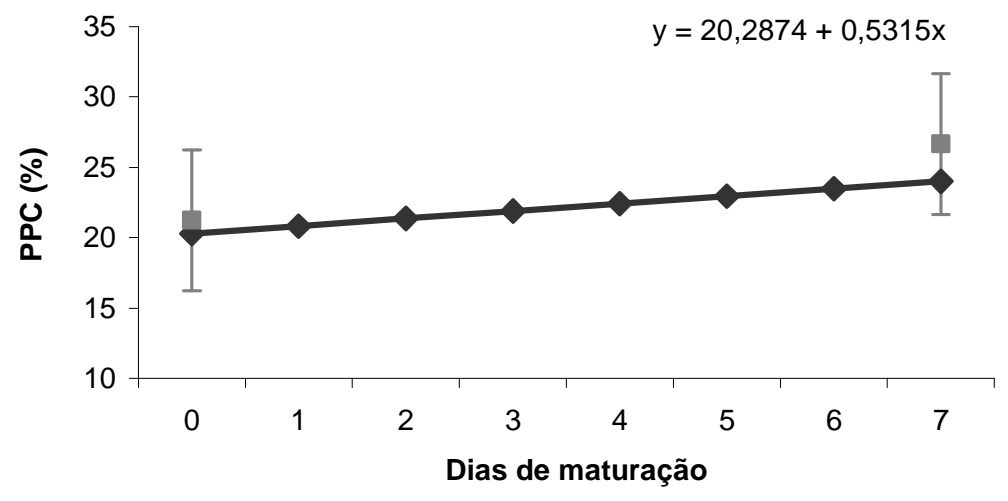

Figura 29. Regressão e equação estimadas das perdas por cocção (PPC) do músculo Longissimus, maturado por sete dias ou não. 
Para a maciez da carne, a maturação proporcionou aumento desta, ou seja, a força de cisalhamento, em kg, empregada foi menor para as carnes maturadas em relação à não maturada (3,42 para 2,64 kg para as não maturadas e maturadas por sete dias, respectivamente) (figura 30).

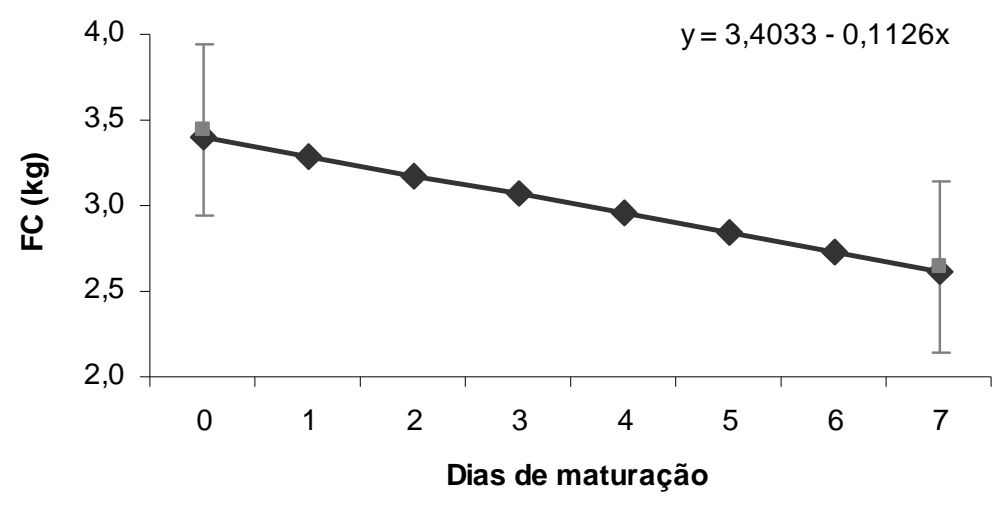

Figura 30. Regressão e equação estimadas da força de cisalhamento (FC) aplicada ao músculo Longissimus, maturado por sete dias ou não.

Todavia, Beauchemin et al. (1997), ao adicionarem misturas enzimáticas em dietas a base de cevada oferecidas à novilhos de corte, observaram um aumento da maciez da carne, ou seja, diminuição da força de cisalhamento, mas destacaram que os mecanismos que proporcionaram essa e outras respostas não ficaram claros, sendo atribuídos, possivelmente, aos efeitos indiretos relacionados com alterações na absorção dos nutrientes, embora os autores não tenham apresentado dados de digestibilidade dos nutrientes. Quando avaliaram as mesmas misturas em dieta a base de milho, ocorreu efeito contrário, com piora da maciez da carne para os animais suplementados com enzima. 


\section{CONCLUSÃO}

O produto enzimático utilizado foi eficiente em melhorar a digestibilidade da FDN, aumentar os protozoários ciliados ruminais e diminuir a perda de água por exsudação da carne sem, contudo, apresentar benefícios para as variáveis de desempenho animal ou outras características de carcaça e da carne avaliadas.

Portanto, o complexo enzimático avaliado não é eficaz para ovinos sob as mesmas condições experimentais citadas no presente estudo. Pelas informações apresentadas, enfatiza-se que, talvez, possa ser possível obter respostas positivas para o produto caso este seja utilizado em ruminantes de outras espécies ou em dieta de alto volumoso ou, ainda, seja adicionado de outra forma ao alimento. 


\section{REFERÊNCIAS}

ASSOCIATION OF OFFICIAL ANALYTICAL CHEMISTS. Official methods of analysis. Ed. 15, Arlington: AOAC, 1990, $1298 \mathrm{p.}$

BEAUCHEMIN, K.A.; McALLISTER, T.A.; DONG, Y.; FARR, B.I.; CHENG, K.J. Effects of mastication on digestion of whole cereal grains by cattle. Journal of Animal Science, v.72, p. 236-246, 1994.

BEAUCHEMIN, K.A.; RODE, L.M.; SEWALT, V.J.H. Fibrolytic enzymes increase fiber digestibility and growth rate of steers fed dry forages. Canadian Journal of Animal Science, v.75, p. 641-644, 1995.

BEAUCHEMIN, K.A.; RODE, L.M. The potential use of feed enzymes for ruminants. In: Proceeding Cornell nutrition conference for feed manufacturers, 1996, New York: Rochester Marriott Thruway Hotel, p.131-141, 1996.

BEAUCHEMIN, K.A.; JONES, S.D.M.; RODE, L.M.; SEWALT, V.J.H. Effect of fibrolytic enzymes in corn or barley diets on performance and carcass characteristics of feedlot cattle. Canadian Journal of Animal Science, v. 77, p. 645-653, 1997.

BEAUCHEMIN, K.A.; YANG, W. Z.; RODE, L.M.K. Effects of Grain Source and enzyme additive on site and extent of nutrient digestion in dairy cows. Journal of Dairy Science, v. 82, p. 378-390, 1999.

BEAUCHEMIN, K.A.; RODE, L.M.; KARREN, D. Use of feed enzymes in feedlot finishing diets. Canadian Journal of Animal Science, v. 79, p. 243-246, $1999 \mathrm{~b}$.

BEAUCHEMIN, K. A.; COLOMBATTO, D.; MORGAVI, D. P.; YANG, W. Z. Use of exogenous fibrolytic enzymes to improve feed utilization by ruminants. Journal of Animal Science, v. 81, supll. 2 p. E37-E47, 2003.

BEDFORD, M.R.; CLASSEN, H.L.; CAMPBELL, G.L The effect of pelleting, salt and pentosanase on viscosity of intestinal contents and performance of broilers fed rye. Poultry Science, v. 70, p. 1571-1577, 1991.

BRAVO, D.; SAUVANT, D.; BOGAERT, C.; MESCHY, F. Quantitative aspects of phosphorus absorption in ruminant. Reproduction Nutrition Development, v. 43, p. 271-284, 2003. 
BUENO, M.S.; CUNHA, E.A.; SANTOS, L.E.; RODA, D.S.; LEINZ, F.F. Características de carcaça de cordeiros suffolk abatidos em diferentes idades. Revista Brasileira de Zootecnia, v. 29, n. 6, p. 1803-1810, 2000.

COLOMBATTO, D.; MOULD, F.L.; BHAT, M.K.; OWEN, E. Use of fibrolytic enzymes to improve the nutritive value of ruminant diets. A biochemical and in vitro rumen degradation assessment. Animal Feed Science and Technology, v. 107 (short communication), p. 201-209, 2003.

COUGHLAN, M.P. The properties of fungal and bacterial cellulases with comment on their production and application. Biotechnol. Genet. Eng. Rev., v. 3, p. 39-109, 1985.

CRUYWAGEN, C.W.; GOOSEN, L. Effect of an exogenous fibrolytic enzyme on growth rate, feed intake and feed conversion ratio in growing lambs. South African Journal of Animal Science, v. 34 (supplement 2), 2004.

DEHORITY, B.A. Rumen Microbiology. Thrumpton, Nottigham, Nottigham University Press, 2003. $372 \mathrm{p}$.

FENG, P.; HUNT, C.W.; PRITCHARD, G.T.; JULIEN, W.E. Effects of enzyme preparations in situ and in vitro degradation and in vivo digestive characteristics of mature cool-season grass. Journal of Animal Science, v. 74, p. 1349-1357, 1996.

FIRKINS, H.J.; RODE, K.A.; McALLISTER, T.A. et al. Effects of feeding fungal culture extract and animal-vegetable fat on degradation of hemicellulose and on ruminal bacterial growth in heifers. Journal of Dairy Science, v. 73, p. 1812-1822, 1990 (supl. 1).

HADDAS, S.G. Associative effects of supplementing barley straw diets with alfalfa hay on rumen environment and nutrient intake and digestibility for ewes. Animal Feed Science and Technology, v. 87, p. 163-171, 2000.

HENDRIX, D.L. Rapid estraction and analyses of nonstructural carbohydrates in plant tissues. Crop Science, v. 33, p. 1306-1311, 1993.

HRISTOV, A.N.; McALLISTER, T.A.; CHENG, K.J. Intraruminal supplementation with increasing levels of exogenous polysaccharide-degrading enzymes: effects on nutrient digestion in cattle fed barley grain diets. Journal of Animal Science, v. 78, p. 477-487, 2000. 
HUNTINGTON, G.B. Starch utilization by ruminants: from basics to the bunk. Journal of Animal Science, v. 75, p. 852-867, 1997.

HONIKEL, K.O. Reference methods for the assessment of physical characteristics of meat. Meat Science, v. 49, n. 4, p. 447-457, 1998.

JUDKINS, M.B.; STOBART, R.H. Influence of two levels of enzyme preparation on ruminal fermentation, particulate and fluid passage and cell wall digestion in wether lambs consuming either a $10 \%$ or $25 \%$ grain diet. Journal of Animal Science, v. 66, p. 1010-1015, 1988.

KRAUSE, M.; BEAUCHEMIN, K.A.; RODE, L.M. et al. Fibrolytic enzyme treatment of barley grain and source of forage in highgrain diets fed to growing cattle. Journal of Animal Science, v. 76, p. 2912-2920, 1998.

KUNG, L.Jr.; TREACHER, R.J.; NAUMAN, G.A.; SMAGALA, A.M.; ENDRES, K.M.; COHEN, M.A. The effect of treating forages with fibrolytic enzymes on its nutritive value and lactation performance of dairy cows. Journal of Dairy Science, v. 83, p. 115-122, 2000.

LEWIS, G.E.; HUNT, C.W.; SANCHEZ, W.K.; TREACHER, R.; PRITCHARD, G.T.; FENG, P. Effect of direct-fed fibrolytic enzymes on the digestive characteristics of a forage-based diet fed to beef steers. Journal of Animal Science, v. 74, p. 30203028, 1996.

LEWIS, G. E.; SANCHEZ, W.K.; HUNT, C.W.; GUY, M.A.; PRITCHARD, G.T.; SWANSON, B.I.; TREACHER, R.J. Effect of direct-fed fibrolytic enzymes on the lactational performance of dairy cows. Journal of Dairy Science, v. 82, p. 611-617, 1999.

LOURES, D.R.S.; NUSSIO, L.G.; PAZIANI, S.F.; PEDROSO, A.F.; MARI, L.J.; RIBEIRO, J.L.; ZOPOLLATTO, M.; SCHMIDT, P.; JUNQUEIRA, M.C.; PACKER, I.U.; CAMPOS, F.P. Efeito de enzimas fibrolíticas e do teor de matéria seca em silagens de capim-tanzânia sobre os parâmetros ruminais, o comportamento ingestivo e a digestão de nutrientes, em bovinos. Revista Brasileira de Zootecnia, v. 34, n. 3, p. 736-745, 2005.

MARTINS, A.S.; VIEIRA, P.F.; BERCHIELLI, T.T.; PRADO, I.N. ; MOLETTA, J.L. Consumo e digestibilidade aparente total em bovinos sob suplementação com enzimas fibrolíticas. Revista Brasileira de Zootecnia, v. 35, n. 5, p. 2118-2124, 2006. 
McALLISTER, T.A.; OOSTING, S.J.; POPP, J.D.; MIR, Z.; YANKE, L.J.; HRISTOV, A.N.; TREACHER, R.J.; CHENG, K.J. Effect of exogenous enzymes on digestibility of barley silage and growth performance of feedlot cattle. Canadian Journal of Animal Science, v. 79, p. 353-360, 1999.

McALLISTER, T.A.; STANFORD, K.; BAE, H.D.; TREACHER, R. J.; HRISTOV, A.N.; BAAH, J.; SHELFORD, J.A.; CHENG, K.J. Effect of a surfactant and exogenous enzymes on digestibility of feed and on growth performance and carcass traits of lambs. Canadian Journal of Animal Science, v. 80, p. 35-44, 2000.

McALLISTER, T.A; HRISTOV, A.N.; BEAUCHEMIN, K.A. et al. Enzymes in ruminant diets. In: BEDFORD, M.R.; PARTRIDGE, G.G. (Eds.) Enzymes in farm animal nutrition, Oxon: Cab International, p. 273-297, 2001.

MENDOZA, G.D.; BRITTON, R.A.; STOCK, R.A. Influence of ruminal protozoa on site and extent of starch digestion and ruminal fermentation. Journal of Dairy Science, v. 71, p. 1572-1578, 1993.

MICHAL, J.J.; JOHNSON, K.A; TREACHER, R.J.; GASKINS, C.T.; SEARS, O. The impact of direct-fed fibrolytic enzymes on the growth rate and feed efficiency of growing beef steers and heifers. Journal of Animal Science, v. 74 (supl. 1), p. 296, 1996 (Abstr.).

MORGAVI, D.P.; BEAUCHEMIN, K.A.; NSEREKO, V.L.; RODE, L.M.; IWAASA, A.D.; YANG, W.Z.; McALLISTER, T.A.; WANG, Y. Synergy between ruminal fibrolytic enzymes and enzymes from Trichoderma longibrachiatum. Journal of Dairy Science, v. 83, p. 1310-1321, 2000.

MORSE, D.; HEAD, H.H.; WILCOX, C.J. Disappearance of Phosphorus in Phytate from Concentrates In Vitro and from Rations Fed to Lactating Dairy Cows. Journal of Dairy Science, v. 75, p. 1979-1986, 1992.

MUWALLA, M.M.; HADDAD, S.G.; HIJAZEEN, M.A. Effect of fibrolytic enzyme inclusion in high concentrate fattening diets on nutrient digestibility and growth performance of Awassi lambs. Livestock Science, v. 111, n. 3, p. 255-258, 2007.

NAKASHIMA, B.A.; MCALLISTER, T.A.; SHARMA, R.; SELINGER, L.B. Diversity of phytases in the rumen. Microbial Ecology, v. 53, p. 82-88, 2007.

NRC. NATIONAL RESEARCH COUNCILNRC. Nutrient requirements of small ruminants: sheep, goats, cervids and new world camelids, 2007, 292 p. 
PRITCHARD, G.; HUNT, J.T.; ALLEN, A.; TREACHER, R. Effect of direct-fed fibrolytic enzymes on digestion and growth performance in feed cattle. Journal of Animal Science, v. 74 (supl. 1), p. 296, 1996 (Abstr.).

RAMIN, A.G.; ASRI, S.; MAJDANI, R. Correlations among serum glucose, betahydroxybutyrate and urea concentrations in non-pregnant ewes. Small Ruminant Research, v. 57, p. 265-269, 2005.

RODE, L.M.; YANG, W.Z.; BEAUCHEMIN, K.A. Fibrolytic enzyme supplements for dairy cows in early lactation. Journal of Dairy Science, v. 82, p. 2121-2126, 1999.

ROJO, R.; MENDOZA, G.D.; GONZÁLEZ, S.S.; LANDOIS, L.; BÁRCENA, R.; CROSBY, M.M. Effects of exogenous amylases from Bacillus licheniformis and Aspergillus niger on ruminal starch digestion and lamb performance. Animal Feed Science and Technology, v. 123-124, p. 655-665, 2005.

SILVA SOBRINHO, A.G.; SAÑUDO, C.; OSÓRIO, J.C.S.; ARRIBAS, M.D.M.C.; OSÓRIO, M.T.M. Produção de carne ovina. Jaboticabal: Funep, 2008, 228 p.

THEURER, B.; WOODS, W. BURROUGHS, W. Influence of enzyme supplements in lamb fattening rations. Journal of Animal Science, v. 22, p. 150-154, 1963.

TRICARICO, J.M.; JOHNSTON, J.D.; DAWSON, K.A.; HANSON, K.C.; McLEOD, K.R.; HARMON, D.L. The effects of an Aspergillus oryzae extract containing alphaamylase activity on ruminal fermentation and milk production in lactating Holstein cows. Animal Science, v. 81, p. 365-374, 2005.

TRICARICO, J.M.; ABNEY, M.D.; GALYEAN, M.L.; RIVERA, J.D.; HANSON, K.C.; MCLEOD, K.R.; HARMON, D.L. Effects of a dietary Aspergillus oryzae extract containing \{alpha\}-amylase activity on performance and carcass characteristics of finishing beef cattle. Journal of Animal Science, v. 85, p. 802-811, 2007.

TRICARICO, J.M.; JOHNSTON, J.D.; DAWSON, K.A. Dietary supplementation of ruminant diets with an Aspergillus oryzae a-amylase. Animal Feed Science and Technology, v. 145, p. 136-150, 2008.

TOWNE, G.; NAGARAJA, T.G.; BRANDT, R.T Jr.; KEMP, K.E. Ruminal ciliated protozoa in cattle fed finishing diets with or without supplemental fat. Journal of Animal Science, v. 68, p. 2150-2155, 1990. 
VAN SOEST, P.J.; ROBERTSON, J.B.; LEWIS, B.A. Methods for dietary fiber, neutral detergent fiber, and nonstarch polysaccharides in relation to animal nutrition. Journal of Dairy Science, v. 74, p. 3583-3597, 1991.

VICINI, J.L.; BATEMAN, H.G.; BHAT, M.K.; CLARK, J.H.; ERDMAN, R.A.; PHIPPS, R.H.; VAN AMBURGH, M.E.; HARTNELL, G.F.; HINTZ, R.L.; HARD, D.L. Effect of feeding supplemental fibrolytic enzymes or soluble sugars with malic acid on milk production. Journal of Dairy Science, v. 86, p. 576-585, 2003.

WALLACE, R.J.;WALLACE, S.J.; McKAIN, N.; NSEREKO, V.L.; HARTNELL, G.F. Influence of supplementary fibrolytic enzymes on the fermentation of corn and grass silages by mixed ruminal microorganisms in vitro. Journal of Animal Science, v. 79, p. 1905-1916, 2001.

WEISS, W.P.; CONRAD, H.R.; PIERRE, N.R.St. A theoretically-based model for predicting total digestible nutrient values of forages end concentrates. Animal Feed Science and Technology, v. 39, p. 95-110, 1992.

YANG, W.Z.; BEACHEMIN, K.A.; RODE, L.M. A Comparison of methods of adding fibrolytic enzymes to lactating cow diets. Journal of Animal Science, v. 83, p. 25122520, 2000. 